\title{
DISTRIBUTION, HABITAT CHARACTERISTICS AND CONSERVATION STATUS OF LEPIDIUM HYSSOPIFOLIUM DESV. (BRASSICACEAE) IN TASMANIA
}

\author{
by Mark Wapstra
}

(with three text-figures, six plates, one table and one appendix)

\begin{abstract}
Wapstra, M. 2018 (14:xii): Distribution, habitat characteristics and conservation status of Lepidium hyssopifolium Desv. (Brassicaceae) in Tasmania. Papers and Proceedings of the Royal Society of Tasmania 152: 33-52. https://doi.org/10.26749/rstpp.152.33 ISSN: 0080-4703. Environmental Consulting Options Tasmania, Lenah Valley, Tasmania 7008, Australia. Email: mark@ecotas.com.au

Lepidium hyssopifolium Desv. (Soft Peppercress) is a threatened vascular plant that is widespread in eastern Tasmania. It is virtually restricted to anthropogenic habitats such as disturbed grassy road verges and the drip-zone of mature ornamental conifers, with very few sites in "natural" habitat (presumed to be some form of native grassland and grassy woodland). A review of database and herbarium collections revealed 87 locations for the species in Tasmania, of which 33 are locally extinct, 30 are of uncertain status and 24 are confirmed as extant. Most subpopulations are localised and of low abundance. The species appears to be resilient and robust to most forms of disturbance, although is absent from areas subject to heavy grazing. Removal of overtopping ornamental trees appears to result in local extinction in the longer term. Complex management of sites along road verges is not considered warranted but continuation of some long-term monitoring at a limited number of sites and active in situ management to minimise risk of heavy disturbance or destruction during road works is appropriate. A review of the formal conservation status of the species suggests that a status of vulnerable under the Tasmanian Threatened Species Protection Act 1995 may be appropriate but that more detailed population information is recommended before a change of status from endangered is made.
\end{abstract}

KeyWords: Lepidium hyssopifolium, Brassicaceae, threatened, endangered, vulnerable, distribution, habitat, conservation, Tasmania.

\section{INTRODUCTION}

Lepidium hyssopifolium Desv. is presently listed as endangered under both the Tasmanian Threatened Species Protection Act 1995 and the Commonwealth Environment Protection and Biodiversity Conservation Act 1999. In Tasmania, the species has long been considered a "weedy native" (e.g., Kirkpatrick \& Gilfedder 1998) because for several decades it appears to have become restricted mainly to anthropogenic habitats.

Most populations occur on road verges, usually associated with mature ornamental pine trees, leading to some speculation that the species may be naturalised rather than native (Wapstra 2018). However, in the absence of unequivocal evidence for its naturalised versus native status, the species remains listed as endangered and should be managed as such.

This paper is the culmination of an extensive examination of database records and herbarium collections undertaken as part of a statewide review of the populations of $L$. hyssopifolium in Tasmania. The combination of desktop review and field assessments has provided the opportunity to update the published information on the distribution, habitat characteristics and conservation management of the species.

\section{METHODS}

\section{Database and collection review}

Three sources of records of $L$. hyssopifolium were interrogated and reviewed to produce a complete list of all known locations of the species in Tasmania. Data from all three sources were used to collate a table of collections/records of $L$. hyssopifolium from Tasmania. All information considered relevant (such as notes on collection sheets and database records regarding habitat, abundance and extent) was transferred to the table.

\section{Tasmanian Herbarium (Tasmanian Museum \& Art Gallery) $(\mathrm{HO})$}

The collection database was interrogated for all collections of Lepidium and this was used to systematically examine every specimen of the genus held at this institute. The main reason all specimens of Lepidium were examined was to ensure that any collections of other species previously misidentified were also considered (for the record, this resulted in one additional specimen of $L$. pseudotasmanicum Thell. being re-determined as L. hyssopifolium).

Every specimen was examined microscopically to confirm its identity as L. hyssopifolium. In some cases, a confirmation slip was added to the collection sheet. This was mainly undertaken for the specimens previously determined as L. tasmanicum, a taxon not currently accepted by the Tasmanian Herbarium and recognised as a nomenclatural synonym of L. hyssopifolium (de Salas \& Baker 2017). Most of the specimens held at HO had previous "det. slips" from people considered as experts in the Brassicaceae and the genus (e.g., H. Hewson, N. Scarlett).

\section{DPIPWE's Natural Values Atlas database (NVA)}

The Natural Values Atlas (NVA) is the Tasmanian government's repository of natural values data, managed by the Tasmanian Department of Primary Industries, Parks, Water \& Environment. The database includes records of flora listed as threatened under the Tasmanian Threatened Species Protection Act 1995 and/or the Commonwealth Environment 
Protection and Biodiversity Conservation Act 1999. The database incorporates most of the data from the Tasmanian Herbarium through a formal data exchange agreement.

Any records in the NVA that are not supported by a voucher at a recognised institute (such as $\mathrm{HO}$ ) need to be treated with caution. While there is a vetting process for data input into the NVA, this is undertaken by DPIPWE staff who can only utilise the available information to make a reasonable decision on inclusion of the supplied data. While for many species this is not an issue (e.g., highly distinctive species), for a species such as L. hyssopifolium, with its attendant (historical) identification issues and the requirement for some level of familiarity and expertise by the observer in its identification, any unvouchered records need to be considered carefully on a case-by-case merit basis.

The Observations Search function of the online database was used to access all records of $L$. hyssopifolium. All data fields were included in the exported output.

\section{Atlas of Living Australia (ALA)}

The Atlas of Living Australia (ALA) is an e-infrastructure that is funded by the Australian Government via its National Collaborative Research Infrastructure Strategy (NCRIS). It is a collaborative partnership of organisations that have stewardship of biological data and expertise in biodiversity informatics, including museums, biological collections, community groups, research organisations, government (State and Commonwealth) and natural resource managers.

The ALA includes data of threatened flora from DPIPWE's NVA and collection information from the Tasmanian Herbarium. It also includes collection information from other Australian herbaria.

The online species search function was used to access all records of $L$. hyssopifolium from the Tasmanian region, with all available fields downloaded as a .csv file.

\section{Field survey}

Field surveys focused on sites under the jurisdiction of the Department of State Growth because the primary aim of the project was to determine the status of previously reported sites to determine if any were suitable for longer term conservation management. However, the surveys were extended to as many of the previously reported sites as possible, with only a limited number on some private properties not assessed (appendix 1 indicates the locations where field surveys were undertaken).

Prior to the field survey, the known locations of $L$. hyssopifolium were reviewed and transferred to field maps showing topography, cadaster and other features as necessary to maximise the chance of detecting the species in the field from the available information. These maps and handheld GPS (Garmin Oregon 650) were used to navigate to the location of the known site. Surveys radiated out (or extended linearly along a road verge) from the known site.

Where L. hyssopifolium was detected, abundance was estimated by direct counts using the waypoint function on the GPS (in most cases) or by estimates (where the species was locally abundant and counting individuals was not practical). The site supporting (or not supporting) the species was described (e.g., vegetation type, geology, disturbance history).

Voucher specimens were collected under DPIPWE permits TFL 15280 and 17029 (in the name of Mark Wapstra), where such voucher material was not already held at $\mathrm{HO}$ and where sufficient material was available for such a collection (some sites with only a low number of plants were not sampled).

Lepidium hyssopifolium was identified in the field by examination of the scapes using a hand-lens (species is characterised by a short grey pubescence). Some material needed to be re-examined by microscope in the laboratory due to loss of most hairs (this occurs with older plants).

\section{RESULTS AND DISCUSSION}

\section{Distribution}

Lepidium hyssopifolium (pl. 1) is widely distributed in eastern Australia, occurring in Tasmania, Victoria, South Australia and New South Wales, and also extends to New Zealand, where it is considered naturalised (Webb et al. 1988).

Within Tasmania, the species is widespread in the eastern half of the State (fig. 1). It occurs in the South East, Northern Midlands, Ben Lomond, and Flinders bioregions (appendix 1), and the Flinders, Break O'Day, Northern Midlands, Southern Midlands, Glamorgan-Spring Bay, Central Highlands, Derwent Valley, Brighton, Sorell, City of Glenorchy, City of Clarence and City of Hobart municipalities (appendix 1).

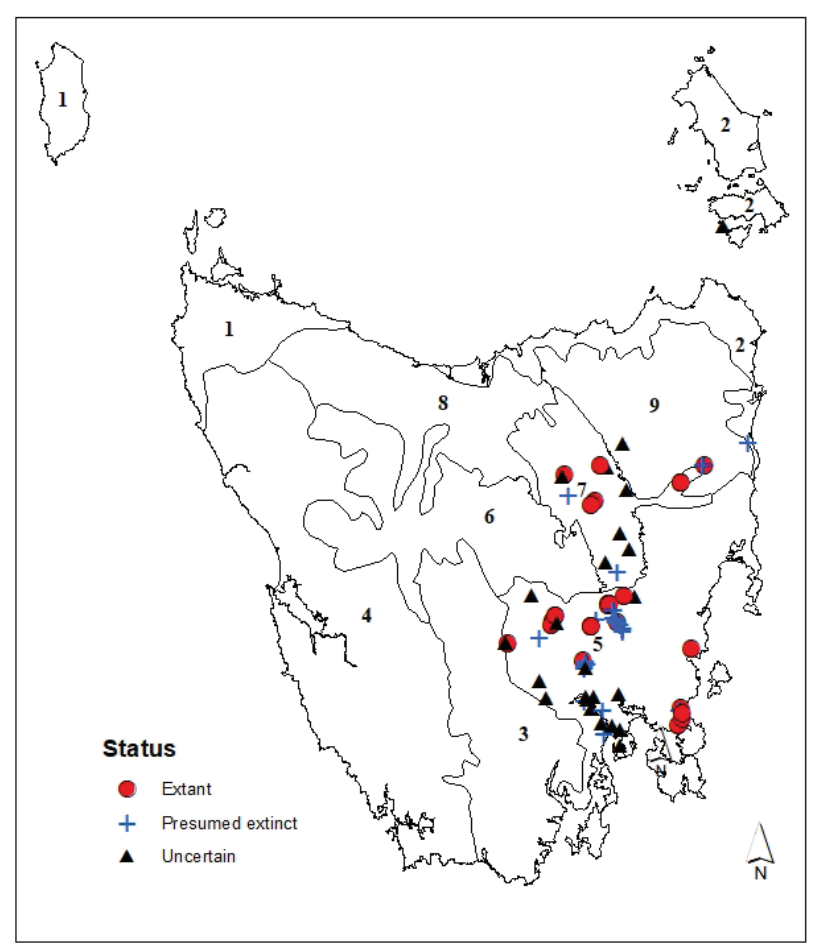

FIG. 1 - Distribution of Lepidium hyssopifolium in Tasmania, showing bioregional boundaries. 1. King; 2 . Furneaux; 3 .

Southern Ranges; 4. West; 5. South East; 6. Central Highlands; 7. Northern Midlands; 8. Northern Slopes; 9. Ben Lomond. 


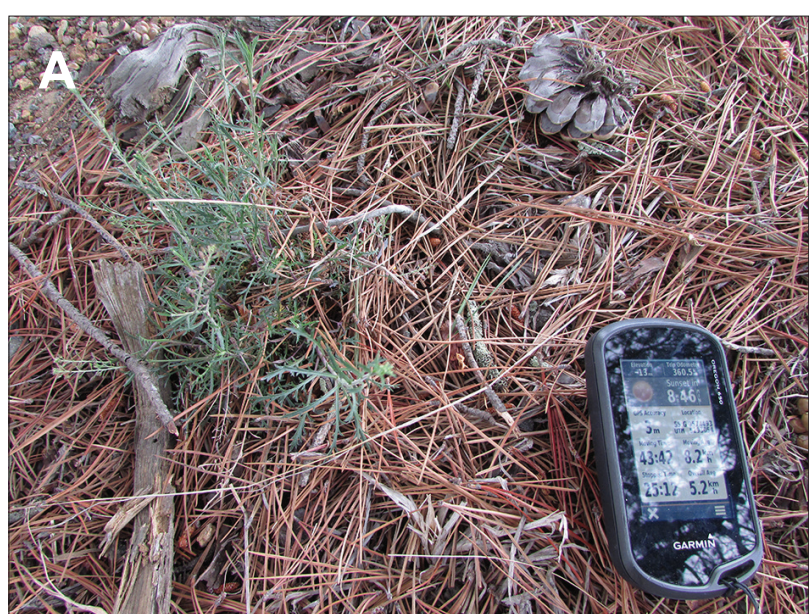

PLATE 1 - (A) Lepidium hyssopifolium growing in situ amongst needles of Pinus radiata (Maclaines Creek, Triabunna, 10 Oct. 2014). (B) Inflorescence and upper leaves showing soft grey pubescence that characterises the species.

\section{Collecting history}

There are two early collections of $L$. hyssopifolium from Tasmania. One is by Archer but this collection is undated and bears no detailed locality information (simply labelled "Tasmania"). His dated collections (NVA - 17 April 2017) include just 42 records, with most from 1848 (18 collections) and 1851 (19 collections), and the balance with just one collection each from the years 1840, 1841, 1862, 1863 and 1877 . His collections are from a wide area but are focused on his places of residence at 'Woolmers' near Longford (Stillwell 1969) and possibly his more frequent travel routes. Nevertheless, this is still evidence of early colonial collection records.

There is also a collection by Gunn, which is the allocated type of $L$. tasmanicum Thell. (a nomenclatural synonym of $L$. hyssopifolium) held at the Berlin Herbarium (image of collection cited online at http://ww2.bgbm.org/ Herbarium). However, this collection is also undated and simply labelled "Hab. Tasmania". The collection probably

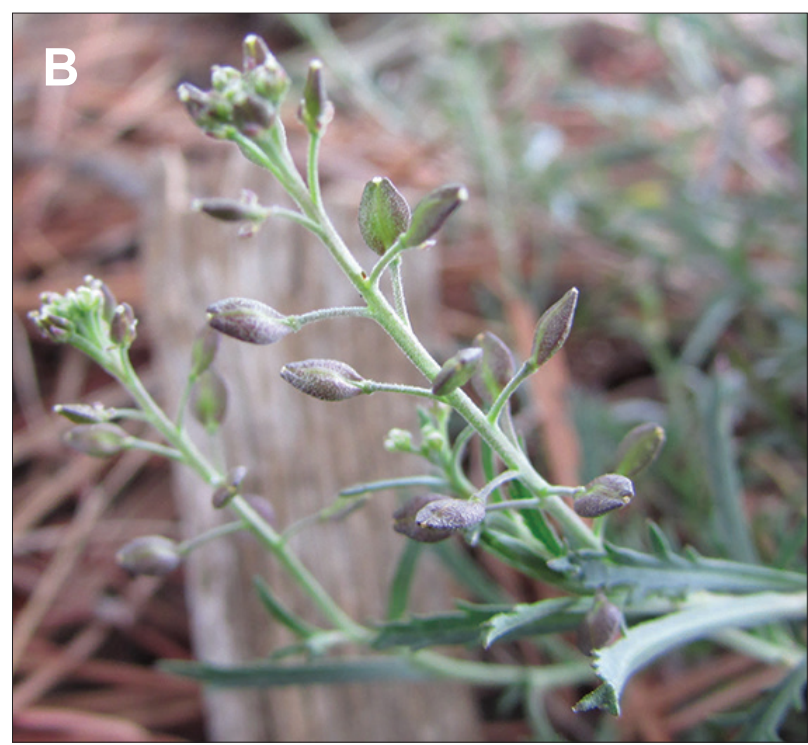

pre-dates Archer's because most of Gunn's collections are from the 1830s and 1840s (Buchanan 1988). The mention by Curtis and Morris (1975, p. 39) of "material collected by R. C. Gunn at Penquite, Launceston” almost certainly refers to the collection held at Berlin (N. Scarlett pers. comm.).

Chronologically, the next collection is by Maiden in 1918, which is labelled "The Ouse". This record is in the ALA but not the NVA so has hitherto escaped consideration at a state level. The next collection is from 1931 (Ralphs Bay, South Arm). Of some note is that the following collection of L. hyssopifolium is from 1974 (Bagdad), a gap of 44 years, which is followed by two collections in 1976 (Preservation Island and Richmond) and one in 1978 (Bridgewater causeway). The next collection is from 1981 (Ross), after which the collections become regular, with only 1983, 1985, 1987, 1988, 1989, 1997, 2000, 2005 and 2013 missing collections (fig. 2).

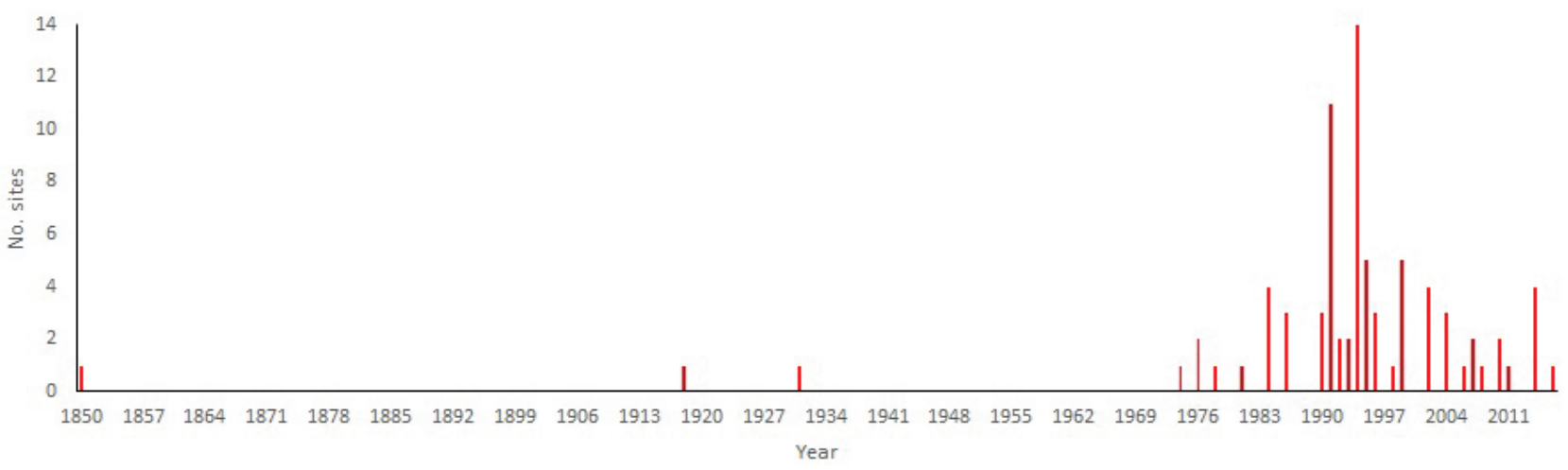

FIG. 2 - Number of sites of Lepidium hyssopifolium added in each year. 

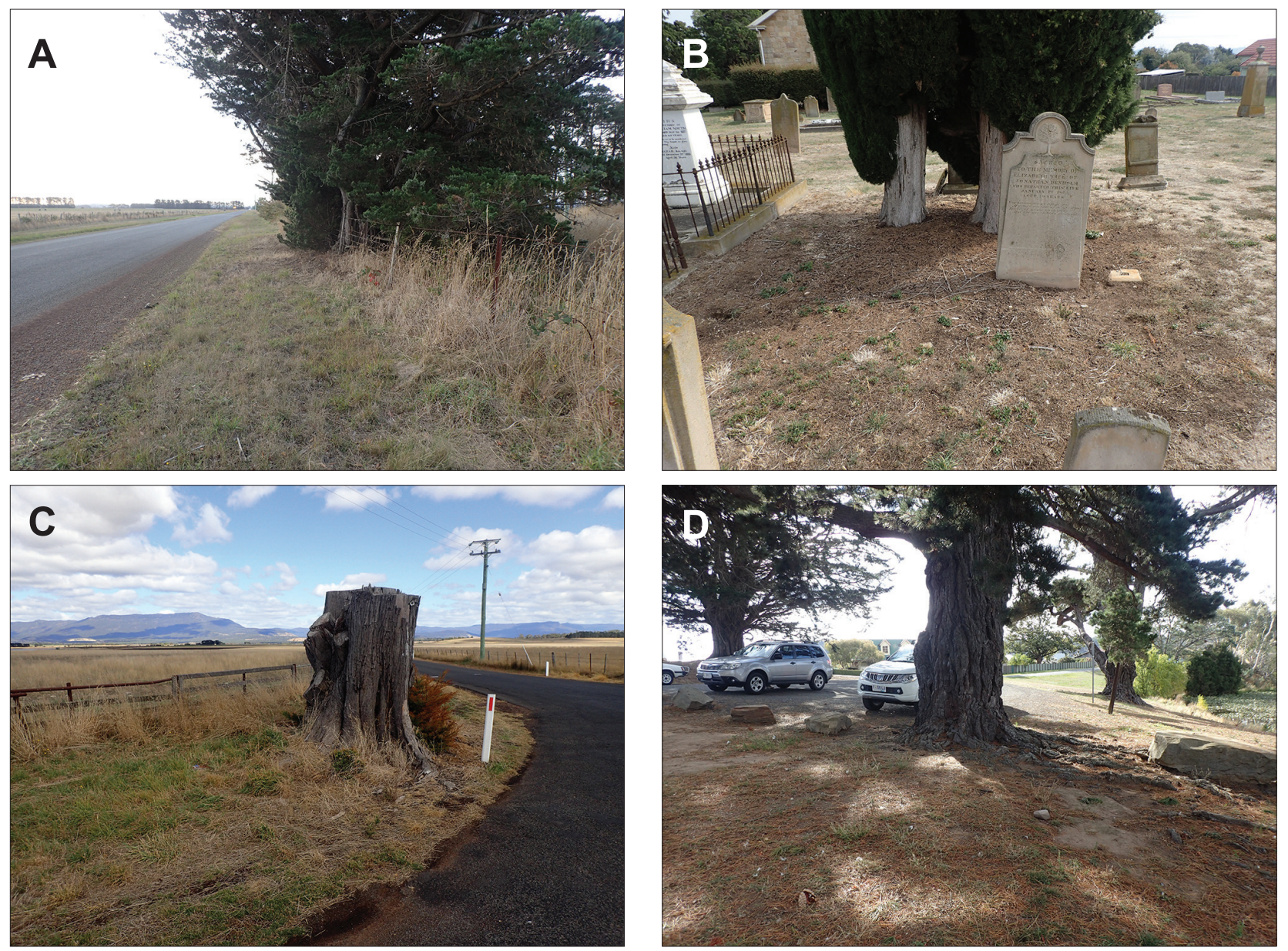

PLATE 2 - Examples of the typical anthropogenic habitat of Lepidium hyssopifolium in Tasmania. (A) Nile Road (frequently slashed exotic grass under Macrocarpa Pine next to stockyards); (B) Bothwell cemetery (rabbit-grazed and dug historic graveyard with ornamental conifers); (C) Valleyfield-Barton roads junction (recently lopped macrocarpa over slashed exotic grass); (D) Oatlands (mature Macrocarpa Pines over gravel car parks).

TABLE 1 - Status of subpopulations of Lepidium hyssopifolium in Tasmania

\begin{tabular}{ll}
\hline Status category & No. \\
\hline Extant & 24 \\
voucher available & 21 \\
voucher absent & 3 \\
Locally extinct & 33 \\
voucher available & 21 \\
voucher absent & 12 \\
Uncertain & 30 \\
voucher available & 15 \\
voucher absent & 15 \\
TOTAL & 87 \\
\hline
\end{tabular}



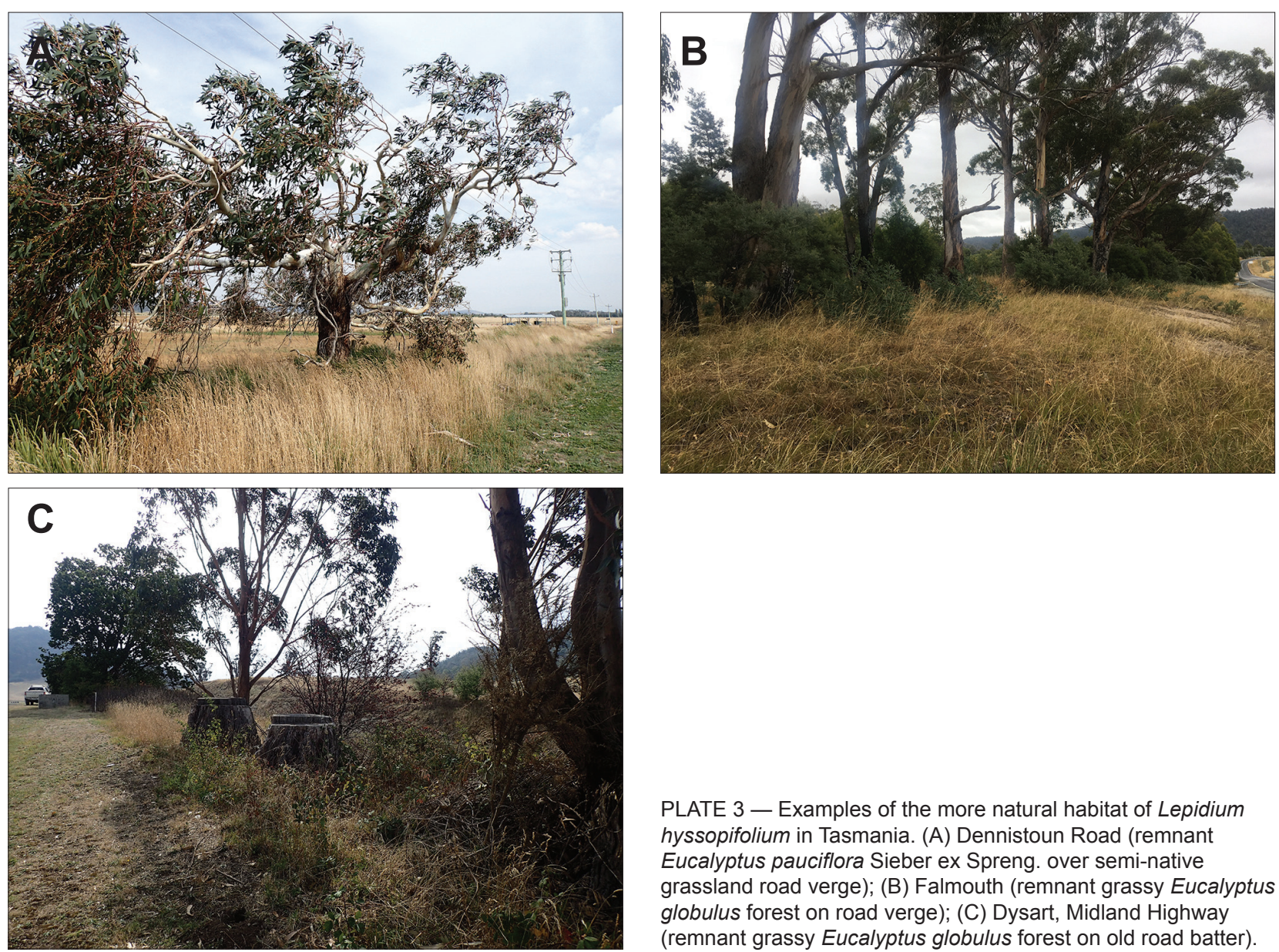

PLATE 3 - Examples of the more natural habitat of Lepidium hyssopifolium in Tasmania. (A) Dennistoun Road (remnant Eucalyptus pauciflora Sieber ex Spreng. over semi-native grassland road verge); (B) Falmouth (remnant grassy Eucalyptus globulus forest on road verge); (C) Dysart, Midland Highway (remnant grassy Eucalyptus globulus forest on old road batter).
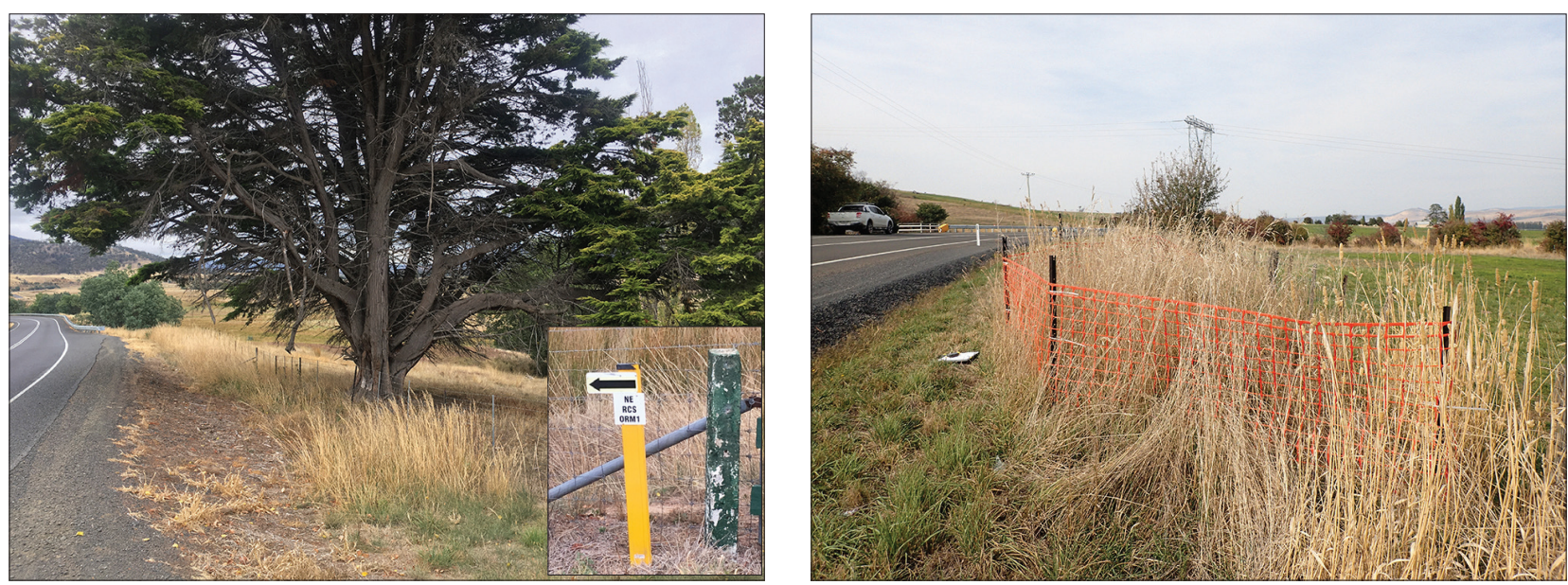

PLATE 4 - Long-term Roadside Conservation Program (Department of State Growth) site for Lepidium hyssopifolium on Esk Main Road near 'Ormley': the species occurs in the dripzone of the ornamental spruce. Inset: State Growth's Roadside Conservation Site marker for the 'Ormley' site.

PLATE 5 - In situ management of highly localised patch of Lepidium hyssopifolium at Fingal Rivulet, where the species occurs amongst sparse grass beneath a mature ornamental Pinus radiata. 


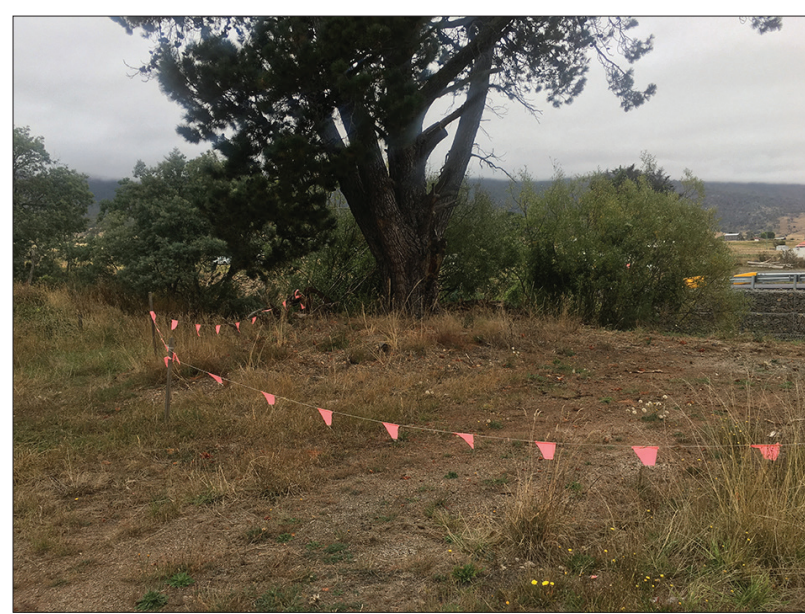

PLATE 6 - In situ management of highly localised patch of Lepidium hyssopifolium on a grassy (weedy) road verge outside Ouse (this is unusual habitat because of the absence of the overtopping mature ornamental conifer).

\section{Habitat characteristics}

Most extant subpopulations of L. hyssopifolium occur in highly modified anthropogenic habitats (pl. 2). The key habitat features are sandy soils below mature ornamental conifers, usually Pinus radiata D.Don (Radiata Pine) and/ or Hesperocyparis macrocarpa (Hartw. ex Gordon) Bartel (Macrocarpa Pine). Almost all extant sites are on road verges, mainly under local government (council) jurisdiction, with a relatively small number under the jurisdiction of the Department of State Growth.

A limited number of sites is associated with "natural" vegetation (pl. 3). (TSS 2003) indicated that Barker \& Johnson (1998) considered the 'Annandale' (private property) at Tunbridge to be especially significant as it is the only relatively natural occurrence of the species. The original collection from this site described the habitat as "Eucalyptus amygdalina woodland, growing under trees of Acacia dealbata". Kirkpatrick \& Gilfedder (1998, p. 468) also regarded this as the site closest to a natural situation for the species, noting: "only one stand, near Tunbridge, has a substantial cover of native plants. Here, Lepidium occurs beneath trees in E. amygdalina woodland that is very occasionally lightly grazed by sheep". The status of this site is uncertain.

A site along East Bagdad Road was originally from under light Eucalyptus viminalis Labill. forest but was on a road verge. A site at Dysart along the old Midland Highway is in highly modified but probably original light eucalypt forest. A site near Falmouth is an interesting "natural" occurrence in that the roadside verge in which the species occurred is a natural (not planted) stand of grassy Eucalyptus globulus Labill. forest. The site at the Mount Nelson Signal Station is in similar vegetation. All these sites are now categorised as locally extinct. An extant site at Spring Hill on the Midland Highway also supports the species under E. globulus but these are planted trees.

\section{Population parameters}

The Scientific Advisory Committee, established under the provisions of the TSPA, produced a set of "Guidelines for Eligibility for Listing under the Threatened Species Protection Act 1995" (DPIW 2008). These Guidelines include definitions of some key population variables that are used in most measures of conservation status, and these are explored below for L. hyssopifolium. These are further explored in the section on the conservation status of the species (table 1).

\section{Number of subpopulations or locations}

The analysis has revealed 87 locations of $L$. hyssopifolium recorded from Tasmania (appendix 1). It is noted that some of these locations are quite close to one another (e.g., locations in Fingal, Oatlands and along Tunnack Road). Of concern is that of the 87 sites/subpopulations known, only $24(28 \%)$ are now considered extant (table 1$)$. Most of these are confirmed by a voucher specimen. However, three still do not have a supporting voucher collection, which is concerning for such an historically confused taxon. Of greater concern is that $33(38 \%)$ of the 87 sites/subpopulations are presumed extinct (table 1). Some of these are a small group of sub-sites along Tunnack Road considered as separate sites but possibly all part of one larger meta-population (this hardly changes the conclusion regarding the trends). Of the 87 sites/subpopulations, 30 (35\%) are classified as uncertain, most with a supporting voucher. Sites without a voucher cannot be guaranteed to be L. hyssopifolium but

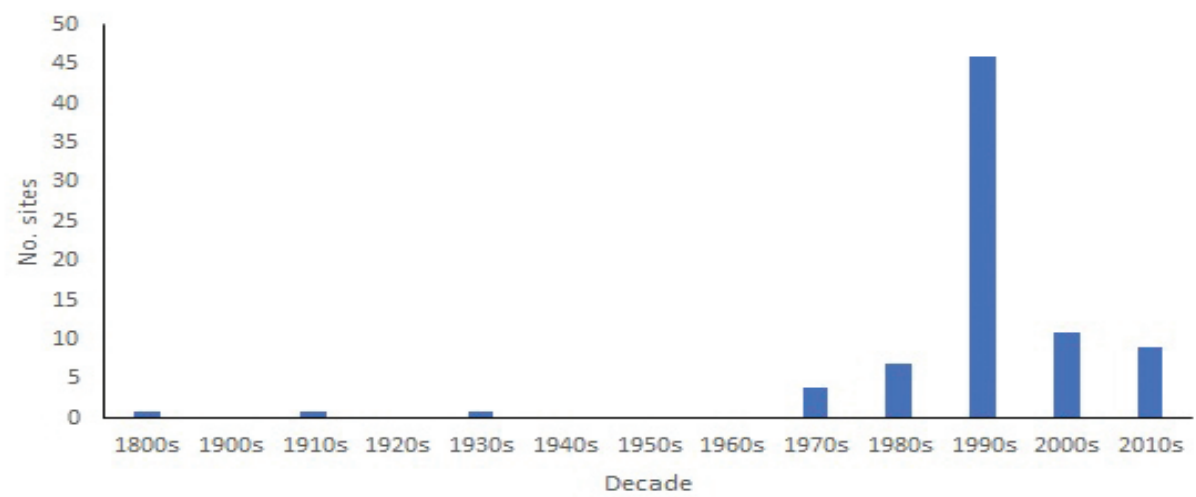

FIG. 3 - Number of sites of Lepidium hyssopifolium added in each decade. 
are included herein because it is not possible to properly discount the sites. Those with vouchers are listed as uncertain mainly because the population has not been confirmed for over a decade.

The conclusion at this stage is that 24 extant populations of $L$. hyssopifolium can be reliably confirmed in Tasmania, that 30 may be extinct, and 33 have an uncertain status.

It is interesting to examine the historical change in the number of subpopulations of L. hyssopifolium in Tasmania (fig. 2). Until the 1970s, there are just four recorded sites for the species. After this time, the records become more frequent, with a high number in the early to mid-1990s. This corresponds to research undertaken by Louise Gilfedder and Jamie Kirkpatrick on the floristics of lowland grassland remnants, and an increase in the number of roadside surveys (as evidenced by records of threatened flora in the Natural Values Atlas). Note that very few of the novel sites are the result of re-determinations of collections previously allocated to other species. When this is viewed by decade (fig. 3), the pattern of novel sites is clearer, with most sites added in the 1990s and 2000s.

\section{Extent of occurrence}

In the case of L. hyssopifolium, it is important to describe how the extent of occurrence was estimated. In the first instance, a minimum convex polygon was created around all populations that can be reasonably considered to be the species. This equates to an extent of occurrence of $19183 \mathrm{~km}^{2}$. If only the confirmed extant subpopulations are included, the extent of occurrence is reduced to about $10-11000 \mathrm{~km}^{2}$.

If the status of the subpopulation is not taken into account, there has been no major change to the extent of occurrence over time because of the collections at Ouse in 1918, at Ralphs Bay in 1931 and on Preservation Island in 1976 , as these three sites provide effective outliers to any minimum convex polygon. That is, while the number of sites has increased (see figs 2, 3), the extent of occurrence has not.

It is difficult to estimate if there has been a change in the extent of occurrence over time because it is not precisely known when subpopulations may have become locally extinct, or the status of many subpopulations. The key measures for the endangered and vulnerable categories under the Guidelines are declines of 50\% over the last ten years and $20 \%$ over the last five years, respectively. As sites such as Nile Road (far north), Maclaines Creek (east), Bream Creek area (southeast), Ouse (southwest) and Bothwell (west) remain extant and have done so for at least the last ten years (based on either the original date of collection and/or an obviously persistent population such as at Nant Lane near Bothwell), there can only have been a minimal reduction in the extent of occurrence over the nominal periods, probably not exceeding the thresholds of $20 \%$ or $50 \%$.

\section{Area of occupancy}

In the case of L. hyssopifolium, it is difficult to estimate the area of occupancy because most records are not accompanied by detailed collection notes. However, most sites appear to be restricted to the growth suppression zone around a few isolated conifers, and such sites generally occupy ca. $10 \mathrm{~m}^{2}-$ even if 50 of the sites had this area of occupancy, the area occupied equates to about 0.05 ha. Some sites are more extensive. For example, around Oatlands, the species is scattered over ca. $500 \mathrm{~m}$ of the fringe of Lake Dulverton and probably occupies $1-2$ ha. It is difficult to conclude that $L$. hyssopifolium has an area of occupancy of greater than ca. 5 ha.

A key question under the Guidelines is whether there has been a reduction in the area of occupancy (same values as for extent of occurrence are applied i.e., 50\% over ten years or $20 \%$ over five years, respectively for the endangered and vulnerable categories). It is unlikely that the area of occupancy has changed to meet or exceed these thresholds, simply because some subpopulations with the greater area of occupancy are long-persistent.

\section{Number of mature individuals}

Estimating the total statewide abundance of mature individuals for $L$. hyssopifolium is difficult due to the lack of information associated with most records. Where information is available, it can be difficult to separate the number of mature individuals from seedlings. This is a difficult concept with the species anyway because often the flush of seedlings, which can achieve "wheatfield" proportions, can include many smaller fertile plants. Most sites do not appear to have more than 100 mature individuals, and many have much less than this. Some sites, however (e.g., Oatlands, Nile Road, Stewarton Bridge), have locally very high abundance, perhaps in the high 100s to low 1000 s of (fertile) individuals. However, even a site such as Stewarton Bridge, which was originally described as a "dense" population (and this is how it appeared in 2017), was only estimated with 47 waypoints (even if each waypoint was up to five plants, the total population is only 235 mature individuals). In my estimate, the statewide population may be in the order of low 1000s but probably does not exceed 10000 mature individuals. Importantly, there are few populations with locally high abundance.

\section{Severely fragmented}

The Guidelines describe "severely fragmented" as the situation in which increased extinction risk to the taxon results from the fact that most of its individuals are found in small and relatively isolated subpopulations, which may go extinct with a low probability of recolonisation. The Guidelines consider fragmentation relevant in relation to flora if it increases the risk of disease or weed invasion by increasing edge effects, increases inbreeding effects, or decreases reproductive output.

For some parts of the species' range, if one population were to become locally extinct, there is little opportunity (in most cases) for recolonisation of that site. For example, the site at Falmouth is now considered locally extinct and based on present knowledge, there appears to be no local source of propagules. However, the fragmentation picture is blurred in some parts of the species' range. For example, there are several reported populations along the Midland Highway, Tunnack Road and Barton Road, 
and along any one of these road features populations of L. hyssopifolium appear to become locally extinct but the species remains present at other sites and there is at least anecdotal evidence for a mechanism of hybridisation. For example, the sites along Tunnack Road may have been created by initial road works and while most sites are now apparently extinct, further road works may re-spread the species from some core sites. Similarly, along the Midland Highway, the loss of one site appears to be "compensated" by the detection of novel sites shortly after. Overall, the statewide distribution of $L$. hyssopifolium is meets the intent of severely fragmented.

\section{Reservation status}

Lepidium hyssopifolium is poorly reserved in Tasmania, and information on its reservation status has been variably interpreted. Kirkpatrick et al. (1991) had identified L. hyssopifolium as an unreserved species and suggested "Bells Lagoon" as a reservation site. This site is located north of Tunbridge Tier Road and is a naturally saline inland lagoon, wholly on private land, with no evidence that $L$. hyssopifolium ever occurred at the site.

TSS (2003, p. 2) states the following regarding the reservation status of the species: "A small population of $L$. hyssopifolium is reserved in the Township Lagoon Nature Reserve [at Tunbridge]. A population occurs in the Sydney Point Historic Site [on Preservation Island], two populations occur in Cemetery Reserves and one population occurs on a council managed Crown Reserve. A population has also been introduced to the Conara Roadside Park (B. Nicholson pers. comm). The largest population occurs in a Private Comprehensive, Adequate and Representative (CAR) Reserve".

The Preservation Island collection from 1976 may be from the Sydney Cove Historic Site (reserved under the Tasmanian Nature Conservation Act 2002), although the precise location from the island is unknown and only part of the island is reserved.

The status of the population reported from the Township Lagoon Nature Reserve (reserved under the Nature Conservation Act 2002) is uncertain, having not been seen since the original collection in 1991/1992 when only four plants were observed. This reserve has received considerable botanical survey in recent years by Threatened Plants Tasmania (Wildcare Inc.), Threatened Species Section (DPIPWE) and many field botanists, and if still present, L. hyssopifolium would likely have been reported.

The population at the Mt Nelson Signal Station is in a Public Reserve (under the Tasmanian Crown Lands Act 1976), although the status of this population is uncertain with recent surveys failing to detect the species.

Parts of the population in Oatlands technically fall within the Lake Dulverton Conservation Area (reserved under the Tasmanian Nature Conservation Act 2002), although most of the population occurs in highly modified habitats utilised for recreation rather than conservation.

Some sites occur in "reserves" managed by local government authorities. For example, the site at Howrah
Beach is in a parkland area managed by City of Clarence and the sites on the Queens Domain are in an area managed largely for their bushland conservation values by City of Hobart (the status of the sites on the Domain is highly uncertain and has not been able to be confirmed despite several targeted surveys). One site (which is now presumed extinct) is in a local government reserve established as part of the Oakdowns development in the City of Clarence.

Wapstra (unpublished data) reviewed the status of the populations of $L$. hyssopifolium in cemeteries and concluded that of the four cemeteries from which the species has been reported (Lake River, Bagdad, Jericho, Bothwell), the species is only extant at Bothwell, where it is under threat from weed invasion and neglect. The assertion in TSS (2008) that "two populations occur in Cemetery Reserves" is considered inaccurate.

The status of this population at 'Annanvale' has not been checked for many years, and as one of the only sites in semi-natural habitat, this is considered a high priority.

Lawrence et al. (2008) reported that L. hyssopifolium occurs in five reserves: one formal reserve in the Flinders bioregion (presumably the Sydney Cove Historic Site), one formal reserve in the Northern Midlands bioregion (presumably the Township Lagoon Nature Reserve), one private reserve in the Northern Midlands bioregion ('Annanvale'), and one informal reserve in each of the Northern Midlands and South East bioregions. These authors allocated the species a status of $3 \mathrm{a}$, which meant it was partially reserved because it is reserved in half or more of the bioregions in which the species occurs (indicates "comprehensiveness" and "representativeness"), a conclusion at odds with the obviously very low reservation status of the species. Apart from the fact that the status of most of the "reserved" populations is at best uncertain, none of the reserves in question have management plans that take account of the species (or any management plans).

Due to the almost exclusive occurrence of $L$. hyssopifolium on road verges, the opportunities for improving the reservation status of the species are limited. In addition, any sites on private property are not ideally suited to negotiating long-term conservation outcomes because of the potential conflicts between land management and the conservation requirements of the species (e.g., eventual need to remove mature pines that appear to form the key component of the habitat for the species).

\section{Conservation management}

Lepidium hyssopifolium occurs mainly in highly modified anthropogenic habitats, leading to some speculation that the species may not be native (Wapstra 2018). However, until definitive evidence is provided to confirm the origin of the species, it should be managed as a native. This then poses a complex question on the most appropriate form of management for a species that appears to be resilient and robust to high levels of disturbance.

Lepidium hyssopifolium was subject to a formal recovery plan (Tumino 2010), although this has not led to significant on-ground actions in Tasmania. 
It is clear that the persistence of L. hyssopifolium in Tasmania will be reliant on actions (or inactions - see below) of local government authorities in combination with private landowners because most of the key extant populations are either on private land and/or councilmanaged road verges adjacent to private property, with only a small number of sites under the jurisdiction of a higher agency (e.g., Department of State Growth; Department of Primary Industries, Parks, Water \& Environment).

In my opinion, there are four broad management options available for L. hyssopifolium in Tasmania, all of which are likely to be necessary in some combination to ensure the survival of the species.

\section{OPTION 1: no management}

Usually active management aims to maintain the population in its current state or improve its status (e.g., increase in numbers). The abundance of L. hyssopifolium at any particular site appears to be unrelated to management actions, except where the management has resulted in the loss of over-topping ornamental trees, which has generally resulted in a decrease in abundance or, in some cases, the complete loss of the population. Active management per se (e.g., active removal of weeds, implementation of a slashing regime) may be unwarranted for most subpopulations. However, without active intervention to prevent the loss or degradation of supporting habitat, localised subpopulations may continue to be lost.

\section{OPTION 2: ex situ conservation}

This is a genuine long-term conservation management option for the species. If there is little (or no) active management of most wild populations, ensuring that the species is represented in ex situ conservation programs is important. The species is already included in collections of the Millennium Seed Bank Project (Dennistoun Road site; J. Wood pers. comm.) and further collections would ensure that the genetic diversity of the species is represented.

It is interesting to note that this management option was recognised at the time of the earlier formal surveys of native grasslands of Tasmania, reported in City Parks and Cemeteries: Tasmania's Remnant Grasslands and Grassy Woodlands (Kirkpatrick et al. 1988, p. 156), with the authors stating: "We have failed to find recently recorded populations of Lepidium hyssopifolium, although we have grown it from Tasmanian seed from a specimen held in the Hobart Herbarium. All recent records of this species in Tasmania are from heavily modified roadsides. Its future in Tasmania depends on the reintroduction into places like the Domain, rather than reservation".

Unlike highly endangered plant species such as Phebalium daviesii Hook.f (Davies Waxflower) or Eucalyptus morrisbyi Brett (Morrisbys Gum) that lend themselves to ornamental plantings, L. hyssopifolium is not likely to be secured by domestic cultivation.

\section{OPTION 3: benign neglect}

This term is used to refer to the current management at almost all sites for $L$. hyssopifolium in Tasmania. That is, there is no active management of the species but routine management of the site supporting the species such as slashing of roadside grass does occur. Sites subject to benign neglect usually support the best performing populations of L. hyssopifolium. For example, many road verge sites (mainly council-managed) are obviously long-persistent and include multi-aged and locally abundant populations. The extreme of this is observed around Oatlands where the species is acting as a weed of gravel car parks and "lawns" in recreation areas. Other examples include sites such as York Plains Road, Nile Road, Stewarton Bridge and 'Ormley', where the species is performing extremely well, despite roadside management or complete neglect. That said, the species may have been lost from some localised sites such as three private cemeteries through benign neglect (although at two of these sites, the neglect took the form of the active removal of the key habitat feature).

Part of the argument for managing L. hyssopifolium by benign neglect is that there is little evidence that dedicating resources for active management of a site results in a manifest benefit to the species. On the contrary, it seems much more likely that for most sites, benign neglect for a decade or two will see the species in much the same state as the present.

\section{OPTION 4: active management}

Active management is appropriate for some sites where the species is directly threatened by proposed works or where there is a risk of removal of a key habitat feature (such as the shadowing ornamental tree). The Department of State Growth has historically managed, and continues to manage, several roadside populations of L. hyssopifolium. Some of these are long-term management sites that form part of the Department's Roadside Conservation Program, for example near 'Ormley' on the Esk Main Road, at which some active management (e.g., slashing, weed removal) occurs, combined with long-term population monitoring (pl. 4). At other sites, management is shorter-term, designed to minimise the risk of local extinction of a population during works. Recent examples of such sites include a culvert replacement on Fingal Rivulet (pl. 5) and surface resealing/weed spraying near Ouse (pl. 6): at both sites, barrier mesh or flagging was erected to successfully minimise risk of disturbance to the individual plants. Ongoing and complex monitoring was not considered warranted for these sites.

Localised active management may be beneficial for $L$. hyssopifolium. There is some evidence that the species may require some kind of disturbance to regenerate, which could include animals scratching in litter (Cropper 1987, Pyrke 1994). Pyrke (1994) simulated animal digging at a highly localised roadside population of $L$. hyssopifolium and found some short-term "resurrection" of the species. The degree to which this level of intervention can contribute to the overall conservation management of the species is not known. 


\section{A review of the formal conservation status of Lepidium hyssopifolium}

Lepidium hyssopifolium is presently listed as endangered under both the Commonwealth Environment Protection and Biodiversity Conservation Act 1999 (EPBCA) and the Tasmanian Threatened Species Protection Act 1995 (TSPA). It is impractical herein to review the conservation status on the EPBCA because that would require substantially more information on its mainland Australian distribution than is available to the author. However, a review of its status on the TSPA is considered warranted because the present documentation has collated essentially all the available information on the species, something that has not been done since the species was first listed on the TSPA.

The Scientific Advisory Committee, established under the provisions of the TSPA, produced a set of "Guidelines for Eligibility for Listing under the Threatened Species Protection Act 1995" (DPIW 2008).

Lepidium hyssopifolium does not properly meet the intent of the criteria for the endangered category. A critical concept in this introductory statement of the Guidelines for the endangered category is a measure of "long-term survival". There is little doubt that L. hyssopifolium has demonstrated such survival, with an increase in the number of populations/locations over time. Another critical concept is knowledge of the "factors causing it to be endangered", which assumes sufficient knowledge to identify such threatening factors and the degree to which they may affect the "long-term survival" prospects of a species. In the case of $L$. hyssopifolium, some threatening processes have been identified, such as removal of overtopping ornamental pines and heavy stock grazing (Kirkpatrick et al. 1988, Kirkpatrick \& Gilfedder 1998). Other threatening factors, such as the degree of impact from roadside management activities, are less well-documented. Irrespective of the factors involved, L. hyssopifolium has persisted at numerous sites in the "long-term" and it has remained present in Tasmania despite these factors operating. On this basis, it is argued that L. hyssopifolium fails the basic test of the endangered category. The species may meet some of the subcriteria but demonstration of this is difficult because many of the estimates of population parameters are missing or nebulous. For example, it is very difficult to justify that there has been an historic reduction in any of the population variables of greater than $50 \%$ in the last 10 years, or that there will be such a reduction projected to be met within the next ten years or three generations. The species does not meet the threshold of $5000 \mathrm{~km}^{2}$ for extent of occurrence but does meet the threshold of $0.1 \mathrm{~km}^{2}$ (10 ha) for area of occupancy. The species has a severely fragmented distribution but the extent of occurrence and area of occupancy is likely to remain quite stable, although the statewide population is likely to continue to show geographic and temporal transience. The concept of "quality of habitat" used in the Guidelines is interesting for a species such as L. hyssopifolium, which appears to rely on the maintenance of quite specific anthropogenic habitats. The overall extent of potential habitat will probably remain quite constant but there may be localised modifications that could cause the species to decline (the fact that it has persisted in the absence of over-topping conifers, however, makes this a hard to apply concept). The statewide population of mature individuals is estimated as fewer than 10000 but it is difficult to justify that it is fewer than 2500 as used in the criteria.

Lepidium hyssopifolium better meets the intent of the criteria for the vulnerable category than the endangered category because the former category "copes" better with limited and nebulous estimates of various populations factors. The species also meets most of the thresholds used in the subcriteria (e.g., fewer than 10000 mature individuals, area of occupancy less than $50 \mathrm{ha}$ ). However, taking a cautionary approach is recommended and it is suggested that the status of species should remain as endangered until more precise estimates of various population parameters are available.

\section{ACKNOWLEDGEMENTS}

Matt Davis, Jillian Jones and Tori Harvey (Department of State Growth) provided initial project coordination, shape files of State Growth road network, and comments on draft documents. Miguel de Salas, Matthew Baker and Kim Hill (Tasmanian Herbarium) provided access to specimens and provision of database information. Andrew North (North Barker Ecosystem Services) provided detailed commentary on a draft table of populations and provision of various reports and management plans. Joe Quarmby (environmental consultant), Grant Daniels (North Barker Ecosystem Services), Richard Schahinger, Wendy Potts and Tim Rudman (DPIPWE) all provided details on various populations. Neville Scarlett provided commentary on the taxonomy of the species and the veracity of historical collections. Lorilee Yeates (Environmental Consulting Options Tasmania) provided field work assistance and discussion of findings. Comments from two anonymous referees improved the manuscript.

\section{REFERENCES}

Barker, P.C.J. \& Johnson, K.A. 1998: Recovery Plan-Selected Tasmanian Forest Associated Plants. Forestry Tasmania, Hobart: 62 pp.

Buchanan, A.M. 1988: The Tasmanian Collecting Localities of Ranald Gunn \& Joseph Milligan. Tasmanian Herbarium Occasional Publication No. 1. Tasmanian Herbarium, Hobart: 56 pp.

Cropper, S. 1987: Ecological notes and suggestions for conservation of a recently discovered site of Lepidium hyssopifolium Desv. (Brassicaceae) at Bolwarrah, Victoria, Australia. Biological Conservation 41: 269-278.

Curtis, W.M. \& Morris, D.M. 1975: The Student's Flora of Tasmania Part 1 (Second Edition). Government Printer, Hobart: 240 pp.

de Salas, M.F. \& Baker, M.L. 2017: A Census of the Vascular Plants of Tasmania, including Macquarie Island. Tasmanian Herbarium, Hobart: 154 pp.

DPIW (Department of Primary Industries \& Water) 2008: Guidelines for Eligibility for Listing under the Threatened 
Species Protection Act 1995. Department of Primary Industries \& Water, Hobart: 8 pp.

Kirkpatrick, J.B. \& Gilfedder, L. 1998: Conserving weedy natives: two Tasmanian endangered herbs in the Brassicaceae. Australian Journal of Ecology 23(5): 466-473.

Kirkpatrick, J.B., Gilfedder, L., Duncan, F. \& Harris, S. 1991: Reservation status and priorities for Tasmanian plants I. Angiospermae (Dicotyledonae). In Banks, M.R., Smith, S.J., Orchard, A.E. \& Kantvilas, G. (eds): Aspects of Tasmanian Botany - A Tribute to Winfred Curtis. Royal Society of Tasmania, Hobart: 163-172.

Kirkpatrick, J., Gilfedder, L. \& Fensham, R. 1988: City Parks and Cemeteries: Tasmania's Remnant Grasslands and Grassy Woodlands. Tasmanian Conservation Trust Inc., Hobart: $268 \mathrm{pp}$.

Lawrence, N., Storey, D. \& Whinam, J. 2008: Reservation Status of Tasmanian Native Higher Plants. Biodiversity Conservation Report 07/1, Department of Primary Industries \& Water, Tasmania: 339 pp.

Pyrke, A.F. 1994: Soil Disturbance by Native Mammals and the Germination and Establishment of Plant Species. Unpublished $\mathrm{PhD}$ thesis, University of Tasmania, Hobart.
Stillwell, G.T. 1969: Archer, William (1820-1874). In Australian Dictionary of Biography. National Centre of Biography, Australian National University. http://adb.anu.edu.au/biography/archer-william-1460/ text4151, published first in hardcopy 1969 , accessed online 17 April 2017.

TSS (Threatened Species Section) 2003: Notesheet for Lepidium hyssopifolium. Department of Primary Industries \& Water, Hobart: 7 pp.

Tumino, M. 2010: National Recovery Plan for the Basalt Peppercress Lepidium hyssopifolium. Department of Sustainability \& Environment, Melbourne: $11 \mathrm{pp}$.

Wapstra, M. 2018: When divine protection is not enough: extinction of Lepidium hyssopifolium Desv. (Brassicaceae) from Tasmanian cemeteries. The Tasmanian Naturalist 140: $33-41$.

Webb, C.J., Sykes, W.R. \& Garnock-Jones, P.J. 1988: Flora of New Zealand. Volume IV. Naturalised Pteridophytes, Gymnosperms, Dicotyledons. Department of Scientific and Industrial Research, Christchurch: 1365 pp.

(accepted 2 October 2018) 
APPENDIX 1 - Summary of sites/subpopulations of Lepidium hyssopifolium within Tasmania. Location names are generally taken from database records or herbarium sheets; those in square brackets are allocated by the author where no location information was given. Habitat notes in quotation marks are taken direct from collection sheets or database records.

\begin{tabular}{|c|c|c|c|}
\hline Location & $\begin{array}{l}\text { (T)enure } \\
\text { (I)BRA } \\
\text { (M) unicipality } \\
\text { (N)RM }\end{array}$ & Comments & Habitat \\
\hline \multicolumn{4}{|l|}{ STATUS: EXTANT } \\
\hline 'Potters Croft' [Dunalley] & $\begin{array}{l}\text { T: private } \\
\text { I: South East } \\
\text { M: Sorell } \\
\text { N: South }\end{array}$ & $\begin{array}{l}\text { 2008: } 12 \text { with unreported extent (not } \\
\text { vouchered) }\end{array}$ & $\begin{array}{l}\text { "Eucalyptus globulus on road } \\
\text { verge". }\end{array}$ \\
\hline $\begin{array}{l}\text { opposite } 470 \text { Bay Road, } \\
\text { Boomer Bay [Marion Bay] }\end{array}$ & $\begin{array}{l}\text { T: local government } \\
\text { I: South East } \\
\text { M: Sorell } \\
\text { N: South }\end{array}$ & $\begin{array}{l}\text { 2008: } 20 \text { with unreported extent (not } \\
\text { vouchered) } \\
\text { 2017: "still there" (A. North pers. } \\
\text { comm.) }\end{array}$ & Unknown. \\
\hline $\begin{array}{l}\text { Burnt Hill Road (southeast) } \\
\text { [Bream Creek] }\end{array}$ & $\begin{array}{l}\text { T: local government } \\
\text { I: South East } \\
\text { M: Sorell } \\
\text { N: South }\end{array}$ & $\begin{array}{l}\text { 2008: } 10 \text { with unreported extent (not } \\
\text { vouchered) } \\
\text { 2016: "still there" (A. North pers. } \\
\text { comm.) }\end{array}$ & "Road gravel in culvert". \\
\hline Bream Creek Road & $\begin{array}{l}\text { T: local government } \\
\text { I: South East } \\
\text { M: Sorell } \\
\text { N: South }\end{array}$ & $\begin{array}{l}\text { 2018: ca. } 10 \text { in ca. } 10 \mathrm{~m} \text { of road verge } \\
\text { (vouchered at } \mathrm{HO} \text { ) }\end{array}$ & $\begin{array}{l}\text { Bare road batter with sparse exotic } \\
\text { grass under mature Pinus radiata. }\end{array}$ \\
\hline $\begin{array}{l}\text { Lyell Highway, ca. } 2 \mathrm{~km} \mathrm{SE} \\
\text { of Ouse }\end{array}$ & $\begin{array}{l}\text { T: State Growth } \\
\text { I: South East } \\
\text { M: Central Highlands } \\
\text { N: South }\end{array}$ & $\begin{array}{l}\text { 2016: } 11 \text { in unspecified area (not } \\
\text { vouchered) } \\
\text { 2017: } 18 \text { in ca. } 2 \text { × } 2 \text { m (vouchered } \\
\text { at } \mathrm{HO} \text { ) }\end{array}$ & $\begin{array}{l}\text { No information available } \\
\text { (presume grassy road verge). }\end{array}$ \\
\hline $\begin{array}{l}\text { Hollow Tree Road (north) } \\
\text { [Bothwell] }\end{array}$ & $\begin{array}{l}\text { T: local government } \\
\text { I: South East } \\
\text { M: Central Highlands } \\
\text { N: South }\end{array}$ & $\begin{array}{l}\text { 2014: } 31 \text { along ca. } 250 \mathrm{~m} \text { of road } \\
\text { verge (vouchered at } \mathrm{HO} \text { ) } \\
\text { 2017: } 30 \text { along ca. } 250 \mathrm{~m} \text { of road } \\
\text { verge }\end{array}$ & $\begin{array}{l}\text { No information available } \\
\text { (presume grassy road verge). }\end{array}$ \\
\hline Bothwell cemetery & $\begin{array}{l}\text { T: private } \\
\text { I: South East } \\
\text { M: Central Highlands } \\
\text { N: South }\end{array}$ & $\begin{array}{l}\text { 1991: no information with database } \\
\text { records (not vouchered) } \\
\text { 2006: } 10 \text { in unspecified area (not } \\
\text { vouchered) } \\
\text { 2017: } 10 \text { s to } 100 \text { s (vouchered at } \mathrm{HO} \text { ) }\end{array}$ & $\begin{array}{l}\text { "Under exotic trees (northern } \\
\text { site under an old Pinus radiata, } \\
\text { western site under ornamental } \\
\text { "macrocarpa"-type conifer around } \\
\text { graves)". }\end{array}$ \\
\hline $\begin{array}{l}\text { Bothwell, } \mathrm{N} \text { of fence } \\
\text { between school and } \\
\text { paddock }\end{array}$ & $\begin{array}{l}\text { T: private } \\
\text { I: South East } \\
\text { M: Central Highlands } \\
\text { N: South }\end{array}$ & $\begin{array}{l}\text { 2014: ca. } 80 \text { in ca. } 200 \mathrm{~m} \text { (vouchered } \\
\text { at HO) } \\
\text { 2017: no evidence but recently mown }\end{array}$ & $\begin{array}{l}\text { Paddock edge under macrocarpa } \\
\text { pines alongside school fence. }\end{array}$ \\
\hline Nant Lane [Bothwell] & $\begin{array}{l}\text { T: local government } \\
\text { I: South East } \\
\text { M: Central Highlands } \\
\text { N: South }\end{array}$ & $\begin{array}{l}\text { 2014: } 220+\text { in ca. } 50 \mathrm{~m} \text { of road verge } \\
\text { (vouchered at HO) } \\
\text { 2017: as } 2014 \text { (not vouchered) }\end{array}$ & $\begin{array}{l}\text { Heavily grazed pasture verge of } \\
\text { gravel lane. }\end{array}$ \\
\hline $\begin{array}{l}\text { Dennistoun Road } \\
\text { [Bothwell] }\end{array}$ & $\begin{array}{l}\text { T: local government } \\
\text { I: South East } \\
\text { M: Central Highlands } \\
\text { N: South }\end{array}$ & $\begin{array}{l}\text { 2007: } 44 \text { in unspecified area } \\
\text { (vouchered at HO) } \\
\text { 2009: } 25 \text { in unspecified area } \\
\text { (vouchered at } \mathrm{HO} \text { ) } \\
\text { 2017: } 2 \text { only }\end{array}$ & $\begin{array}{l}\text { Weedy/grassy road verge under } \\
\text { remnant Eucalyptus pauciflora. }\end{array}$ \\
\hline Dysart Drive (north) & $\begin{array}{l}\text { T: local government/ } \\
\text { private? } \\
\text { I: South East } \\
\text { M: Southern Midlands } \\
\text { N: South }\end{array}$ & $\begin{array}{l}\text { 1991: no information with collection } \\
\text { (vouchered at HO) } \\
\text { 2002: } 6 \text { at base of two trees } \\
\text { (vouchered at HO) } \\
\text { 2009: } 4 \text { in unspecified area (not } \\
\text { vouchered) } \\
\text { 2017: } 4\end{array}$ & $\begin{array}{l}\text { Under Eucalyptus globulus } \\
\text { (planted?). }\end{array}$ \\
\hline
\end{tabular}




\begin{tabular}{|c|c|c|c|}
\hline Location & $\begin{array}{l}\text { (T)enure } \\
\text { (I)BRA } \\
\text { (M) unicipality } \\
\text { (N)RM }\end{array}$ & Comments & Habitat \\
\hline Maclaines Creek, Triabunna & $\begin{array}{l}\text { T: State Growth } \\
\text { I: South East } \\
\text { M: Glamorgan-Spring } \\
\text { Bay } \\
\text { N: South }\end{array}$ & $\begin{array}{l}\text { 2004: } 5 \text { (not vouchered) } \\
\text { 2006: ca. } 60 \text { (vouchered at HO) } \\
\text { 2015: } 1 \text { (not vouchered) } \\
\text { 2016: } 50 \text { (not vouchered) }\end{array}$ & Under ornamental pines. \\
\hline $\begin{array}{l}\text { Spring Hill, Midland } \\
\text { Highway }\end{array}$ & $\begin{array}{l}\text { T: State Growth } \\
\text { I: South East } \\
\text { M: Southern Midlands } \\
\text { N: South }\end{array}$ & $\begin{array}{l}\text { 2014: } 6 \text { database records } \\
\text { (one vouchered at } \mathrm{HO} \text { ) with } \\
25+7+15+8+10 \text { specified } \\
\text { 2017: } 3 \text { sites of } 43,21 \text { and } 34 \\
\text { individuals }\end{array}$ & $\begin{array}{l}\text { "Under Eucalyptus globulus } \\
\text { [planted] and planted/weedy } \\
\text { exotic Acacia species with dense } \\
\text { grass on highway batter". }\end{array}$ \\
\hline $\begin{array}{l}\text { Edge of Lake Dulverton, } \\
\text { Oatlands }\end{array}$ & $\begin{array}{l}\text { T: Lake Dulverton } \\
\text { Conservation Area \& } \\
\text { local government } \\
\text { I: South East } \\
\text { M: Southern Midlands } \\
\text { N: South }\end{array}$ & $\begin{array}{l}\text { 1994: no information with collection } \\
\text { (vouchered at HO) } \\
\text { 2017: 100s of fertile plants and } \\
\text { perhaps } 1000 \text { s of seedlings (vouchered } \\
\text { at HO) }\end{array}$ & $\begin{array}{l}\text { Beneath pines at edge of lake } \\
\text { but also numerous individuals } \\
\text { scattered around picnic tables, } \\
\text { rubbish bins and in the gravel of } \\
\text { the road. }\end{array}$ \\
\hline $\begin{array}{l}\text { [Oatlands, Esplanade, } \\
\text { between Barrack Street and } \\
\text { Mill Point] }\end{array}$ & $\begin{array}{l}\text { T: Lake Dulverton } \\
\text { Conservation Area \& } \\
\text { local government } \\
\text { I: South East } \\
\text { M: Southern Midlands } \\
\text { N: South }\end{array}$ & $\begin{array}{l}\text { 1994: no information with collection } \\
\text { (vouchered at HO) } \\
\text { 2017: } 100 \text { s of fertile plants and } \\
\text { perhaps } 1000 \text { s of seedlings (vouchered } \\
\text { at HO) }\end{array}$ & $\begin{array}{l}\text { Under pines along road and lake } \\
\text { verge. }\end{array}$ \\
\hline [Oatlands, 'Weedington'] & $\begin{array}{l}\text { T: local government \& } \\
\text { private? } \\
\text { I: South East } \\
\text { M: Southern Midlands } \\
\text { N: South }\end{array}$ & $\begin{array}{l}\text { 1999: no information with collection } \\
\text { (not vouchered) } \\
\text { 2017: } 100 \text { s in front of property along } \\
\text { road verge (vouchered at HO) }\end{array}$ & Sandy road verge under old pines. \\
\hline Oatlands, Mahers Point & $\begin{array}{l}\text { T: local government } \\
\text { I: South East } \\
\text { M: Southern Midlands } \\
\text { N: South }\end{array}$ & $\begin{array}{l}\text { 2007: ca. } 20+(\text { vouchered at HO) } \\
\text { 2016: ca. } 20+\end{array}$ & $\begin{array}{l}\text { Sandy gravelly soil under old } \\
\text { macrocarpa pines. }\end{array}$ \\
\hline $\begin{array}{l}\text { York Plains Road, near } \\
\text { Coffin Gully Creek }\end{array}$ & $\begin{array}{l}\text { T: local government } \\
\text { I: South East } \\
\text { M: Southern Midlands } \\
\text { N: South }\end{array}$ & $\begin{array}{l}\text { 1995: no information with collection } \\
\text { (vouchered at HO) } \\
\text { 2017: } 18 \text { in ca. } 20 \text { m of pine } \\
\text { windbreak (vouchered at HO) }\end{array}$ & $\begin{array}{l}\text { Under Pinus radiata and } \\
\text { Hespercyparis macrocarpa over } \\
\text { dense grass. }\end{array}$ \\
\hline $\begin{array}{l}\text { Barton Road at Stewarton } \\
\text { Bridge }\end{array}$ & $\begin{array}{l}\text { T: private } \\
\text { I: Northern Midlands } \\
\text { M: Northern Midlands } \\
\text { N: North }\end{array}$ & $\begin{array}{l}\text { 1994: no information with collection } \\
\text { (not vouchered) } \\
\text { 2001: dense population } \\
\text { 2017: 10s to low 1000s (vouchered } \\
\text { at HO) }\end{array}$ & $\begin{array}{l}\text { Under row of mature Pinus } \\
\text { radiata on private property next to } \\
\text { old stockyards and on gravel track. }\end{array}$ \\
\hline $\begin{array}{l}\text { Junction of Barton Road } \\
\text { and Valleyfield Road }\end{array}$ & $\begin{array}{l}\text { T: local government } \\
\text { I: Northern Midlands } \\
\text { M: Northern Midlands } \\
\text { N: North }\end{array}$ & $\begin{array}{l}\text { 1994: no information with collection } \\
\text { (vouchered at HO) } \\
\text { 2017: } 7 \text { within } 3 \text { m of base of old } \\
\text { macrocarpa (vouchered at HO) }\end{array}$ & $\begin{array}{l}\text { Original site noted as being } \\
\text { "under Cupressus macrocarpa" but } \\
\text { this tree has now been chopped } \\
\text { down (re-sprouting) and species } \\
\text { occurs amongst dense grass on } \\
\text { road verge. }\end{array}$ \\
\hline
\end{tabular}


APPENDIX 1 - cont.

\begin{tabular}{|c|c|c|c|}
\hline Location & $\begin{array}{l}\text { (T)enure } \\
\text { (I)BRA } \\
\text { (M) unicipality } \\
\text { (N)RM }\end{array}$ & Comments & Habitat \\
\hline Ormley, Esk Main Road & $\begin{array}{l}\text { T: private \& State } \\
\text { Growth } \\
\text { I: Northern Midlands } \\
\text { M: Break O’Day } \\
\text { N: North }\end{array}$ & $\begin{array}{l}\text { 1998: no information with collection } \\
\text { (vouchered at HO) } \\
\text { 2002: approximately two dozen plants } \\
\text { close to drip line of tree (vouchered } \\
\text { at HO) } \\
\text { 2012: } 60 \text { in } 50 \mathrm{~m} 2 \\
\text { 2016: } 15 \text { ( } 12 \text { in road reserve } 3 \text {, over } \\
\text { fence) } \\
\text { 2017: ca. } 200-250 \text { (mature and } \\
\text { seedlings); numerous seedlings missed } \\
\text { amongst now quite dense grass; no } \\
\text { estimate of individuals made on north } \\
\text { side of fence on private property (but } \\
\text { going very well - } 10 \text { s to low } 100 \text { s) }\end{array}$ & $\begin{array}{l}\text { "Growing beneath the shadow } \\
\text { of a cypress tree, with Einadia } \\
\text { nutans, Bromus diandrus, Plantago } \\
\text { coronopus, Hypochoeris radicata, } \\
\text { Dactylis glomerata". }\end{array}$ \\
\hline $\begin{array}{l}\text { East of Fingal. Esk Main } \\
\text { Road at Fingal Culvert no. } \\
\text { B3169 }\end{array}$ & $\begin{array}{l}\text { T: private (State Growth } \\
\text { works adjacent) } \\
\text { I: Ben Lomond } \\
\text { M: Break O’Day } \\
\text { N: North }\end{array}$ & $\begin{array}{l}\text { 2014: ca. } 25 \text { plants around Pinus } \\
\text { radiata (vouchered at HO) } \\
\text { 2017: } 50-100+\text { around original P. } \\
\text { radiata and } 1 \text { to east under different } \\
\text { P. radiata }\end{array}$ & $\begin{array}{l}\text { "Sandy soil, weeds, grass beneath } \\
\text { mature } P \text {. radiata on road verge". }\end{array}$ \\
\hline $\begin{array}{l}\text { [Macquarie Road, Cressy, } \\
\text { road to pump station] }\end{array}$ & $\begin{array}{l}\text { T: local government } \\
\text { I: Northern Midlands } \\
\text { M: Northern Midlands } \\
\text { N: North }\end{array}$ & $\begin{array}{l}\text { 1994: no information with record } \\
\text { (not vouchered) } \\
\text { 2017: } 7 \text { in } 10 \times 2 \mathrm{~m} \text { (vouchered at } \\
\text { HO) }\end{array}$ & $\begin{array}{l}\text { Southern side of road under } \\
\text { mature macrocarpa pines } \\
\text { (growing on private land) but } L . \\
\text { hyssopifolium in gravel of road } \\
\text { verge. }\end{array}$ \\
\hline Nile Road & $\begin{array}{l}\text { T: local government } \& \\
\text { private } \\
\text { I: Northern Midlands } \\
\text { M: Northern Midlands } \\
\text { N: North }\end{array}$ & $\begin{array}{l}\text { 1994: no information with record } \\
\text { (not vouchered) } \\
\text { 2016: ca. } 500 \text { ("wheat field of } \\
\text { seedlings") in } 20-30 \text { x } 4 \text { m of road } \\
\text { verge (vouchered at HO) } \\
\text { 2017: thinned out but counting was } \\
\text { difficult because of recent roadside } \\
\text { slashing }\end{array}$ & $\begin{array}{l}\text { Eastern verge of Nile Road } \\
\text { underneath a row of macrocarpa } \\
\text { pines (growing on private land) } \\
\text { but } L . \text { hyssopifolium in gravel/ } \\
\text { slashed grass of road verge. }\end{array}$ \\
\hline \multicolumn{4}{|l|}{ STATUS: UNCERTAIN } \\
\hline Ralphs Bay & $\begin{array}{l}\text { T: uncertain } \\
\text { I: South East } \\
\text { M: City of Clarence } \\
\text { N: South }\end{array}$ & $\begin{array}{l}\text { 1931: } 3 \text { specimen sheets at HO (same } \\
\text { collector, date and location) with no } \\
\text { notes } \\
\text { 2017: could not be re-located but } \\
\text { original location unknown }\end{array}$ & Unknown. \\
\hline Glebe, Oakdowns & $\begin{array}{l}\text { T: Local Government } \\
\text { Act Reserve } \\
\text { I: South East } \\
\text { M: City of Clarence } \\
\text { N: South }\end{array}$ & $\begin{array}{l}\text { 2004: } 2 \text { records ( } 3+\text { or } 5 \text { individuals) } \\
\text { reported from a } 1 \text { x } 2 \text { m area (not } \\
\text { vouchered) } \\
\text { 2017: extensive search in vicinity } \\
\text { of database records revealed only L. } \\
\text { pseudotasmanicum and L. africanum }\end{array}$ & $\begin{array}{l}\text { Light Eucalyptus viminalis grassy } \\
\text { woodland with ornamentals } \\
\text { and mown "lawns" (retained } \\
\text { subdivision "reserve"). }\end{array}$ \\
\hline $\begin{array}{l}\text { Howrah Beach, Wentworth } \\
\text { Park }\end{array}$ & $\begin{array}{l}\text { T: Crown } \\
\text { I: South East } \\
\text { M: City of Clarence } \\
\text { N: South }\end{array}$ & $\begin{array}{l}\text { 2004: } 4 \text { individuals with unreported } \\
\text { extent (vouchered at HO) } \\
\text { 2017: extensive searching in vicinity } \\
\text { of record failed to detect the species } \\
\text { (L. africanum widespread and } \\
\text { abundant) }\end{array}$ & $\begin{array}{l}\text { "Amongst Phragmites australis } \\
\text { behind dunes, beside track". }\end{array}$ \\
\hline
\end{tabular}




\begin{tabular}{|c|c|c|c|}
\hline Location & $\begin{array}{l}\text { (T)enure } \\
\text { (I)BRA } \\
\text { (M) unicipality } \\
\text { (N)RM }\end{array}$ & Comments & Habitat \\
\hline Domain & $\begin{array}{l}\text { T: local government } \\
\text { I: South East } \\
\text { M: City of Hobart } \\
\text { N: South }\end{array}$ & $\begin{array}{l}\text { 1995: no information with database } \\
\text { records (not vouchered) } \\
\text { 2014-2017: several searches by the } \\
\text { author (and colleagues) have failed } \\
\text { to detect the species anywhere on the } \\
\text { Domain, with L. africanum and L. } \\
\text { pseudotasmanicum being widespread } \\
\text { and locally common }\end{array}$ & $\begin{array}{l}\text { "Growth suppression zones in the } \\
\text { shade of several cedars long the } \\
\text { Soldiers Memorial Walk". }\end{array}$ \\
\hline $\begin{array}{l}\text { Burnt Hill Road (junction } \\
\text { with Bream Creek Road) } \\
\text { [Bream Creek] }\end{array}$ & $\begin{array}{l}\text { T: local government } \\
\text { I: South East } \\
\text { M: Sorell } \\
\text { N: South }\end{array}$ & $\begin{array}{l}\text { 1993: no information with database } \\
\text { records (not vouchered) } \\
\text { 2000: last seen but in decline (A. } \\
\text { North pers. comm.) } \\
\text { 2017: extensive search but not found }\end{array}$ & "Dense grass on road verge". \\
\hline $\begin{array}{l}\text { Knights Point, Windermere } \\
\text { Bay Reserve [Claremont] }\end{array}$ & $\begin{array}{l}\text { T: local government } \\
\text { I: South East } \\
\text { M: City of Glenorchy } \\
\text { N: South }\end{array}$ & $\begin{array}{l}\text { 1986: no information with database } \\
\text { records (not vouchered) }\end{array}$ & $\begin{array}{l}\text { "Coastal point, with Einadia } \\
\text { nutans". }\end{array}$ \\
\hline Bridgewater Causeway & $\begin{array}{l}\text { T: State Growth } \\
\text { I: South East } \\
\text { M: Brighton/Derwent } \\
\text { Valley? } \\
\text { N: South }\end{array}$ & $\begin{array}{l}\text { 1978: no information with collection } \\
\text { (vouchered at CANB) }\end{array}$ & No information available. \\
\hline $\begin{array}{l}\text { Granton, } 14 \mathrm{~km} \mathrm{NE} \text { of New } \\
\text { Norfolk. Derwent River, } S \\
\text { bank (E side of bridge) }\end{array}$ & $\begin{array}{l}\text { T: local government or } \\
\text { TasRail } \\
\text { I: South East } \\
\text { M: City of Glenorchy } \\
\text { N: South }\end{array}$ & $\begin{array}{l}\text { 1986: } 20-25 \text { in unspecified area } \\
\text { (vouchered at HO) }\end{array}$ & $\begin{array}{l}\text { "Between the roadside and railway } \\
\text { line, south bank of Derwent } \\
\text { River". }\end{array}$ \\
\hline Cove Hill & $\begin{array}{l}\text { T: private property } \\
\text { I: South East } \\
\text { M: Brighton } \\
\text { N: South }\end{array}$ & 2006: 2 in $1 \times 1 \mathrm{~m}$ (vouchered at $\mathrm{HO}$ ) & $\begin{array}{l}\text { "Degraded Eucalyptus viminalis } \\
\text { grassy woodland on dolerite". }\end{array}$ \\
\hline Richmond & $\begin{array}{l}\text { T: unknown } \\
\text { I: South East } \\
\text { M: City of Clarence } \\
\text { N: South }\end{array}$ & $\begin{array}{l}\text { 1976: no information associated with } \\
\text { collection (vouchered at QVMAG) }\end{array}$ & No information available. \\
\hline $\begin{array}{l}\text { Salmon Ponds ca. } 8 \mathrm{~km} \\
\text { NW of New Norfolk }\end{array}$ & $\begin{array}{l}\text { T: uncertain } \\
\text { I: South East } \\
\text { M: Derwent Valley } \\
\text { N: South }\end{array}$ & $\begin{array}{l}\text { 1986: } 25-50 \text { in unspecified area } \\
\text { (vouchered at HO) } \\
\text { 2017: Extensive search of road } \\
\text { verges of highway and road into } \\
\text { Salmon Ponds only revealed extensive } \\
\text { populations of L. pseudotasmanicum }\end{array}$ & $\begin{array}{l}\text { "Roadside shoulder, with } \\
\text { Lepidium pseudotasmanicum". }\end{array}$ \\
\hline $\begin{array}{l}\text { Lyell Highway, opposite } \\
\text { Woolpack Road }\end{array}$ & $\begin{array}{l}\text { T: uncertain } \\
\text { I: South East } \\
\text { M: Central Highlands } \\
\text { N: South }\end{array}$ & $\begin{array}{l}\text { 1993: no information associated with } \\
\text { record (not vouchered) } \\
\text { 2017: general survey of road verges in } \\
\text { area unsuccessful }\end{array}$ & $\begin{array}{l}\text { No information available } \\
\text { (presume grassy road verge). }\end{array}$ \\
\hline 'The Ouse' & $\begin{array}{l}\text { T: unknown } \\
\text { I: South East } \\
\text { M: Central Highlands } \\
\text { N: South }\end{array}$ & $\begin{array}{l}\text { 1918: no information with collection } \\
\text { (vouchered at NSW) }\end{array}$ & No information available. \\
\hline Bothwell & $\begin{array}{l}\text { T: unknown } \\
\text { I: South East } \\
\text { M: Central Highlands } \\
\text { N: South }\end{array}$ & $\begin{array}{l}\text { 1991: no information with collection } \\
\text { (vouchered at HO) }\end{array}$ & No information available. \\
\hline
\end{tabular}


APPENDIX 1 - cont.

\begin{tabular}{|c|c|c|c|}
\hline Location & $\begin{array}{c}\text { (T)enure } \\
\text { (I)BRA } \\
\text { (M) unicipality } \\
\text { (N)RM }\end{array}$ & Comments & Habitat \\
\hline Bothwell tip & $\begin{array}{l}\text { T: local government } \\
\text { I: South East } \\
\text { M: Central Highlands } \\
\text { N: South }\end{array}$ & $\begin{array}{l}1991 \& \text { \& 1993: no information with } \\
\text { database records or collection (1993 } \\
\text { vouchered at HO) }\end{array}$ & $\begin{array}{l}\text { "Heathy Eucalyptus tenuiramis } \\
\text { woodland. Weedy area above tip } \\
\text { face". }\end{array}$ \\
\hline Hermitage & $\begin{array}{l}\text { T: uncertain } \\
\text { I: South East } \\
\text { M: Central Highlands } \\
\text { N: South }\end{array}$ & $\begin{array}{l}\text { 1984: no information with record } \\
\text { (not vouchered) }\end{array}$ & No information available. \\
\hline $\begin{array}{l}\text { Bagdad, SE corner of } \\
\text { training track }\end{array}$ & $\begin{array}{l}\text { T: private } \\
\text { I: South East } \\
\text { M: Southern Midlands } \\
\text { N: South }\end{array}$ & $\begin{array}{l}\text { 1990: no information with record } \\
\text { (not vouchered) }\end{array}$ & Assume open paddock. \\
\hline $\begin{array}{l}\text { Bagdad } \\
\text { [middle of training track] }\end{array}$ & $\begin{array}{l}\text { T: private } \\
\text { I: South East } \\
\text { M: Southern Midlands } \\
\text { N: South }\end{array}$ & $\begin{array}{l}\text { 1990: no information with record } \\
\text { (vouchered at HO) }\end{array}$ & "In horse paddock". \\
\hline $\begin{array}{l}\text { Private Paddock, E Bagdad } \\
\text { Rd }\end{array}$ & $\begin{array}{l}\text { T: private } \\
\text { I: South East } \\
\text { M: Southern Midlands } \\
\text { N: South }\end{array}$ & $\begin{array}{l}\text { 1999: ca. } 5-10 \text { in unspecified area (not } \\
\text { vouchered) }\end{array}$ & "Paddock". \\
\hline Dysart junction area & $\begin{array}{l}\text { T: local government/ } \\
\text { private? } \\
\text { I: South East } \\
\text { M: Southern Midlands } \\
\text { N: South }\end{array}$ & $\begin{array}{l}\text { 1984, } 1995 \text { \& 2003: no information } \\
\text { with record (none vouchered) } \\
\text { 2017: extensive search but not found }\end{array}$ & No information available. \\
\hline $\begin{array}{l}\text { [Tunnack Road, ca. } 200 \mathrm{~m} \\
\text { W of 'Woodstock'] }\end{array}$ & $\begin{array}{l}\text { T: State Growth } \\
\text { I: South East } \\
\text { M: Southern Midlands } \\
\text { N: South }\end{array}$ & $\begin{array}{l}1994 \text { \& 2002: no information with } \\
\text { records (not vouchered) } \\
2017: 7 \text { in ca. } 5 \mathrm{~m} \text { of road verge }\end{array}$ & Dense grass on road verge. \\
\hline $\begin{array}{l}\text { 'Kewstoke' } \\
\text { York Plains }\end{array}$ & $\begin{array}{l}\text { T: local government } \\
\text { I: South East } \\
\text { M: Southern Midlands } \\
\text { N: South }\end{array}$ & $\begin{array}{l}\text { 1995: no information with collection } \\
\text { (vouchered at HO) }\end{array}$ & $\begin{array}{l}\text { "In tree planting, old conifers cut } \\
\text { down, very weedy". }\end{array}$ \\
\hline river bank at Ross & $\begin{array}{l}\text { T: local government? } \\
\text { I: South East } \\
\text { M: Southern Midlands } \\
\text { N: South }\end{array}$ & $\begin{array}{l}\text { 1981: no information with collection } \\
\text { (vouchered at HO) } \\
\text { 2017-2018: bases of all old pine trees } \\
\text { around Ross township surveyed but } \\
\text { only L. pseudotasmanicum located in } \\
\text { historic church yard }\end{array}$ & "Around trunks of old pines". \\
\hline $\begin{array}{l}\text { 'Annanvale' property } \\
\text { [Tunbridge] }\end{array}$ & $\begin{array}{l}\text { T: private } \\
\text { I: Northern Midlands } \\
\text { M: Northern Midlands } \\
\text { N: North }\end{array}$ & $\begin{array}{l}\text { 1990: no information with collection } \\
\text { (vouchered at HO) } \\
\text { 1993: no information with collection } \\
\text { (not vouchered) }\end{array}$ & $\begin{array}{l}\text { "Eucalyptus amygdalina woodland, } \\
\text { growing under trees of Acacia } \\
\text { dealbata". }\end{array}$ \\
\hline $\begin{array}{l}\text { 'Fosterville', Campbell } \\
\text { Town [Ross] }\end{array}$ & $\begin{array}{l}\text { T: private } \\
\text { I: Northern Midlands } \\
\text { M: Northern Midlands } \\
\text { N: North }\end{array}$ & $\begin{array}{l}\text { unknown date: no information with } \\
\text { collection (vouchered at } \mathrm{HO} \text { ) }\end{array}$ & No information available. \\
\hline $\begin{array}{l}\text { Ellerslie property, Kingston } \\
\text { Road }\end{array}$ & $\begin{array}{l}\text { T: private } \\
\text { I: Northern Midlands } \\
\text { M: Northern Midlands } \\
\text { N: North }\end{array}$ & $\begin{array}{l}\text { 1994: no information with collection } \\
\text { (vouchered at HO) } \\
\text { 2017: no evidence of Lepidium } \\
\text { hyssopifolium (no Lepidium species) } \\
\text { on either side of road beneath rows of } \\
\text { mature pine }\end{array}$ & $\begin{array}{l}\text { Row of mature pine trees on road } \\
\text { verge. }\end{array}$ \\
\hline
\end{tabular}


APPENDIX 1 - cont.

\begin{tabular}{|c|c|c|c|}
\hline Location & $\begin{array}{l}\text { (T)enure } \\
\text { (I)BRA } \\
\text { (M) unicipality } \\
\text { (N)RM }\end{array}$ & Comments & Habitat \\
\hline [Cressy, west of school] & $\begin{array}{l}\text { T: unknown (presume } \\
\text { local government) } \\
\text { I: Northern Midlands } \\
\text { M: Northern Midlands } \\
\text { N: North }\end{array}$ & $\begin{array}{l}\text { 1994: no information with record } \\
\text { (not vouchered) }\end{array}$ & No information available. \\
\hline $\begin{array}{l}\text { 'Glen Mavis', Deddington } \\
\text { Road }\end{array}$ & $\begin{array}{l}\text { T: local government } \\
\text { I: Northern Midlands } \\
\text { M: Northern Midlands } \\
\text { N: North }\end{array}$ & $\begin{array}{l}\text { 1994: no information with collection } \\
\text { (vouchered at HO) }\end{array}$ & "Beneath pines". \\
\hline $\begin{array}{l}\text { 'Clarendon' [probably local } \\
\text { government road] }\end{array}$ & $\begin{array}{l}\text { T: uncertain (local } \\
\text { government?) } \\
\text { I: Northern Midlands } \\
\text { M: Northern Midlands } \\
\text { N: North }\end{array}$ & $\begin{array}{l}\text { 1994: no information with record } \\
\text { (not vouchered) } \\
2016 \text { \& 2017: both sides of road into } \\
\text { 'Clarendon' were surveyed from Nile } \\
\text { Road but the species was not detected }\end{array}$ & $\begin{array}{l}\text { Mature pine trees over grass } \\
\text { between road and paddocks. }\end{array}$ \\
\hline $\begin{array}{l}\text { 'Blessington', west of } \\
\text { O’Briens Road }\end{array}$ & $\begin{array}{l}\text { T: private } \\
\text { I: Ben Lomond } \\
\text { M: Northern Midlands } \\
\text { N: North }\end{array}$ & $\begin{array}{l}\text { 1995: no information with record } \\
\text { (vouchered at HO) }\end{array}$ & "Farmyard". \\
\hline $\begin{array}{l}\text { Cove Point, Preservation } \\
\text { Island }\end{array}$ & $\begin{array}{l}\text { T: Sydney Cove } \\
\text { Historic Site? } \\
\text { I: Flinders } \\
\text { M: Flinders Island } \\
\text { N: North }\end{array}$ & $\begin{array}{l}\text { 1976: no information with record } \\
\text { (vouchered at CANB) }\end{array}$ & No information available. \\
\hline Tasmania [Archer] & $\begin{array}{l}\text { T: unknown } \\
\text { I: unknown } \\
\text { M: unknown } \\
\text { N: unknown }\end{array}$ & $\begin{array}{l}\text { 1840-1873: no information with } \\
\text { record (vouchered at HO) }\end{array}$ & No information available. \\
\hline Tasmania [Gunn] & $\begin{array}{l}\text { T: unknown } \\
\text { I: unknown } \\
\text { M: unknown } \\
\text { N: unknown }\end{array}$ & $\begin{array}{l}\text { 1830s-1840s: no information with } \\
\text { record (vouchered at BER) }\end{array}$ & No information available. \\
\hline \multicolumn{4}{|c|}{ STATUS: PRESUMED EXTINCT } \\
\hline $\begin{array}{l}\text { Mount Nelson Signal } \\
\text { Station }\end{array}$ & $\begin{array}{l}\text { T: Public Reserve (Parks } \\
\& \text { Wildlife Service) } \\
\text { I: South East } \\
\text { M: City of Hobart } \\
\text { N: South }\end{array}$ & $\begin{array}{l}\text { 2002: } 2 \text { records ( } 14+2 \text { individuals) } \\
\text { with unreported extent (vouchered at } \\
\text { HO) } \\
\text { 2017: could not be re-located despite } \\
\text { extensive search of Signal Station area }\end{array}$ & $\begin{array}{l}\text { Light Eucalyptus globulus grassy } \\
\text { forest but highly modified with } \\
\text { roads, car parks, buildings and } \\
\text { mown lawns. }\end{array}$ \\
\hline Black Snake Road, Granton & $\begin{array}{l}\text { T: local government } \\
\text { I: South East } \\
\text { M: City of Glenorchy } \\
\text { N: South }\end{array}$ & $\begin{array}{l}\text { 1991: } 1 \text { plant (vouchered at HO) } \\
\text { 2017: could not be re-located despite } \\
\text { extensive search along most of Black } \\
\text { Snake Road }\end{array}$ & $\begin{array}{l}\text { "Road verge under a large } \\
\text { Eucalyptus viminalis". }\end{array}$ \\
\hline Shones Corner, Risdon & $\begin{array}{l}\text { T: State Growth } \\
\text { I: South East } \\
\text { M: City of Clarence } \\
\text { N: South }\end{array}$ & $\begin{array}{l}1992 \text { \& 1993: no information with } \\
\text { database records (not vouchered) } \\
\text { 2002: ca. } 40 \text { (vouchered at HO) } \\
\text { 2009: no longer present (internal State } \\
\text { Growth report) } \\
\text { 2017: extensive search but not found }\end{array}$ & $\begin{array}{l}\text { Weedy bank of Risdon Brook } \\
\text { under Acacia dealbata. }\end{array}$ \\
\hline $\begin{array}{l}\text { Hollow Tree Road (south) } \\
\text { [Hollow Tree] }\end{array}$ & $\begin{array}{l}\text { T: local government } \\
\text { I: South East } \\
\text { M: Central Highlands } \\
\text { N: South }\end{array}$ & $\begin{array}{l}\text { 2011: } 3 \text { with unreported extent (not } \\
\text { vouchered) } \\
2014 \& 2017 \text { : could not be re-located } \\
\text { despite extensive search along ca. } 500 \\
\text { m each side of database records on } \\
\text { both sides of road }\end{array}$ & Dense grass on road verge. \\
\hline
\end{tabular}


APPENDIX 1 - cont.

\begin{tabular}{|c|c|c|c|}
\hline Location & $\begin{array}{l}\text { (T)enure } \\
\text { (I)BRA } \\
\text { (M) unicipality } \\
\text { (N)RM }\end{array}$ & Comments & Habitat \\
\hline $\begin{array}{l}\text { Bagdad Uniting Church, } \\
\text { Chauncy Vale Road }\end{array}$ & $\begin{array}{l}\text { T: private } \\
\text { I: South East } \\
\text { M: Southern Midlands } \\
\text { N: South }\end{array}$ & $\begin{array}{l}\text { 1999: }<10 \text { in unspecified area } \\
\text { (vouchered at HO) } \\
\text { 2017: could not be re-located (L. } \\
\text { pseudotasmanicum present) }\end{array}$ & $\begin{array}{l}\text { Under old radiata pine in grave } \\
\text { yard. }\end{array}$ \\
\hline Midland Highway, Bagdad & $\begin{array}{l}\text { T: State Growth } \\
\text { I: South East } \\
\text { M: Southern Midlands } \\
\text { N: South }\end{array}$ & $\begin{array}{l}\text { 1974: no information (vouchered at } \\
\text { HO) } \\
\text { 1982: common (vouchered at HO) } \\
\text { 1991 \& 1993: no information with } \\
\text { database records (not vouchered) } \\
\text { 2015: no longer present (A. North } \\
\text { pers. comm.) } \\
\text { 2017: not surveyed }\end{array}$ & "Sandy and mown road verge". \\
\hline $\begin{array}{l}\text { East side of road opposite } \\
\text { the Bagdad Caltex Service } \\
\text { Station, } 10 \mathrm{~km} \mathrm{~N} \text { of the } \\
\text { Pontville Bridge on the } \\
\text { Midland Highway }\end{array}$ & $\begin{array}{l}\text { T: State Growth } \\
\text { I: South East } \\
\text { M: Southern Midlands } \\
\text { N: South }\end{array}$ & $\begin{array}{l}\text { 1984: } 15 \text { large plants and } 30- \\
40 \text { seedlings and smaller plants } \\
\text { along short distance of road verge } \\
\text { (vouchered at HO) } \\
\text { 1990: } 50 \text { (A. North pers. comm.) } \\
\text { 2000: no longer present (A. North } \\
\text { pers. comm.) } \\
\text { 2017: not surveyed }\end{array}$ & $\begin{array}{l}\text { "Dark brown clay-loam on mown } \\
\text { road verge now dominated by } \\
\text { introduced grass species. Adjacent } \\
\text { paddocks extensively cleared and } \\
\text { heavily grazed". }\end{array}$ \\
\hline $\begin{array}{l}\text { E Bagdad Rd jct, Midland } \\
\text { Hwy }\end{array}$ & $\begin{array}{l}\text { T: State Growth } \\
\text { I: South East } \\
\text { M: Southern Midlands } \\
\text { N: South }\end{array}$ & $\begin{array}{l}1995 \text { \& 1999: no information with } \\
\text { database records (not vouchered) } \\
\text { 2017: could not be re-located (site } \\
\text { now highly modified and "site lost to } \\
\text { roadworks at this junction", A. North } \\
\text { pers. comm.) }\end{array}$ & $\begin{array}{l}\text { "Mown traffic island on west side } \\
\text { of highway". }\end{array}$ \\
\hline East Bagdad Road & $\begin{array}{l}\text { T: local government } \\
\text { I: South East } \\
\text { M: Southern Midlands } \\
\text { N: South }\end{array}$ & $\begin{array}{l}\text { 1991: "dense and thick stand" in } \\
\text { unspecified area (vouchered at HO) } \\
\text { 1999: } 50 \text { (vouchered at HO) } \\
\text { 2017: extensive search along several } \\
\text { hundred metres of each side of Esat } \\
\text { Bagdad Road failed to find te species } \\
\text { (L. pseudotasmanicum was present) } \\
\text { and apparently the site was buried by } \\
\text { Council road maintenan ce (fill) in the } \\
\text { late 1990s (A. North pers. comm.) }\end{array}$ & $\begin{array}{l}\text { "Under Eucalyptus viminalis on } \\
\text { very disturbed roadside mound on } \\
\text { side of road". }\end{array}$ \\
\hline Dysart Drive (south) & $\begin{array}{l}\text { T: State Growth } \\
\text { I: South East } \\
\text { M: Southern Midlands } \\
\text { N: South }\end{array}$ & $\begin{array}{l}\text { 1994: } 1 \text { plant (vouchered at HO) } \\
\text { 1995: no information with record } \\
\text { 2007: no information with record } \\
\text { 2017: could not be re-located }\end{array}$ & $\begin{array}{l}\text { "Amongst roadside grasses and } \\
\text { weeds in open". }\end{array}$ \\
\hline Jericho cemetery & $\begin{array}{l}\text { T: private } \\
\text { I: South East } \\
\text { M: Southern Midlands } \\
\text { N: South }\end{array}$ & $\begin{array}{l}\text { 1991: no information with collections } \\
\text { (two vouchers at HO) } \\
\text { 2017: extensive search of cemetery } \\
\text { revealed no individuals }\end{array}$ & $\begin{array}{l}\text { "Degraded native grassland } \\
\text { under } P \text {. radiata with Vittadinia } \\
\text { gracilis, Einadia nutans, Bromus } \\
\text { sterilis". Supporting pine tree now } \\
\text { removed. }\end{array}$ \\
\hline Jericho Road & $\begin{array}{l}\text { T: local government } \\
\text { I: South East } \\
\text { M: Southern Midlands } \\
\text { N: South }\end{array}$ & $\begin{array}{l}\text { 1999: no information with record } \\
\text { (not vouchered) } \\
\text { 2017: could not be re-located despite } \\
\text { extensive search along ca. } 200 \mathrm{~m} \text { each } \\
\text { side of database record on both sides } \\
\text { of road }\end{array}$ & Presume grassy/weedy road verge. \\
\hline $\begin{array}{l}\text { [Baden, junction of } \\
\text { Tunnack Road and } \\
\text { Woodsdale Road] }\end{array}$ & $\begin{array}{l}\text { T: State Growth } \\
\text { I: South East } \\
\text { M: Southern Midlands } \\
\text { N: South }\end{array}$ & $\begin{array}{l}\text { 1999: no information with record } \\
\text { (not vouchered) } \\
\text { 2017: could not be re-located despite } \\
\text { extensive search along ca. } 200 \text { m each } \\
\text { side of database record on both sides } \\
\text { of road }\end{array}$ & Presume grassy/weedy road verge. \\
\hline
\end{tabular}


APPENDIX 1 - cont.

\begin{tabular}{|c|c|c|c|}
\hline Location & $\begin{array}{c}\text { (T)enure } \\
\text { (I)BRA } \\
\text { (M)unicipality } \\
\text { (N)RM }\end{array}$ & Comments & Habitat \\
\hline $\begin{array}{l}\text { [Tunnack Road near } \\
\text { 'Woodside' property] }\end{array}$ & $\begin{array}{l}\text { T: State Growth } \\
\text { I: South East } \\
\text { M: Southern Midlands } \\
\text { N: South }\end{array}$ & $\begin{array}{l}\text { 2002: no information with record } \\
\text { (not vouchered) } \\
\text { 2017: could not be re-located despite } \\
\text { extensive search along ca. } 200 \mathrm{~m} \text { each } \\
\text { side of database record on both sides } \\
\text { of road }\end{array}$ & Presume grassy/weedy road verge. \\
\hline $\begin{array}{l}\text { [Tunnack Road near 'Lint } \\
\text { Hill' property] }\end{array}$ & $\begin{array}{l}\text { T: State Growth } \\
\text { I: South East } \\
\text { M: Southern Midlands } \\
\text { N: South }\end{array}$ & $\begin{array}{l}\text { 2002: no information with record } \\
\text { (not vouchered) } \\
\text { 2017: could not be re-located despite } \\
\text { extensive search along ca. } 200 \mathrm{~m} \text { each } \\
\text { side of database record on both sides } \\
\text { of road }\end{array}$ & Presume grassy/weedy road verge. \\
\hline $\begin{array}{l}\text { [ca. } 500 \text { m NE of Tunnack } \\
\text { Road on 'Woodstock' near } \\
\text { Tin Dish Rivulet] }\end{array}$ & $\begin{array}{l}\text { T: State Growth } \\
\text { I: South East } \\
\text { M: Southern Midlands } \\
\text { N: South }\end{array}$ & $\begin{array}{l}\text { 1994: no information with record } \\
\text { (not vouchered) } \\
\text { 2017: could not be re-located despite } \\
\text { extensive search along ca. } 200 \text { m each } \\
\text { side of database record on both sides } \\
\text { of road }\end{array}$ & Presume grassy/weedy road verge. \\
\hline $\begin{array}{l}\text { [Tunnack Road, ca. } 150 \\
\text { N of Black Gate Road } \\
\text { junction] }\end{array}$ & $\begin{array}{l}\text { T: State Growth } \\
\text { I: South East } \\
\text { M: Southern Midlands } \\
\text { N: South }\end{array}$ & $\begin{array}{l}\text { 1996: no information with record } \\
\text { (not vouchered) } \\
\text { 2017: could not be re-located despite } \\
\text { extensive search along ca. } 200 \text { m each } \\
\text { side of database record on both sides } \\
\text { of road }\end{array}$ & Presume grassy/weedy road verge. \\
\hline $\begin{array}{l}\text { [Tunnack Road, ca. } 300 \\
\text { m S of entrance to 'View } \\
\text { Banks'] }\end{array}$ & $\begin{array}{l}\text { T: State Growth } \\
\text { I: South East } \\
\text { M: Southern Midlands } \\
\text { N: South }\end{array}$ & $\begin{array}{l}\text { 1996: no information with record } \\
\text { (not vouchered) } \\
\text { 2017: could not be re-located despite } \\
\text { extensive search along ca. } 200 \mathrm{~m} \text { each } \\
\text { side of database record on both sides } \\
\text { of road }\end{array}$ & Presume grassy/weedy road verge. \\
\hline $\begin{array}{l}\text { [Tunnack Road, 'View } \\
\text { Banks'] }\end{array}$ & $\begin{array}{l}\text { T: State Growth } \\
\text { I: South East } \\
\text { M: Southern Midlands } \\
\text { N: South }\end{array}$ & $\begin{array}{l}\text { 1994: no information with record } \\
\text { (not vouchered) } \\
\text { 2017: could not be re-located despite } \\
\text { extensive search along ca. } 200 \text { m each } \\
\text { side of database record on both sides } \\
\text { of road }\end{array}$ & Presume grassy/weedy road verge. \\
\hline $\begin{array}{l}\text { [Tunnack Road, ca. } 350 \mathrm{~N} \\
\text { of entrance to 'Tramore'] }\end{array}$ & $\begin{array}{l}\text { T: State Growth } \\
\text { I: South East } \\
\text { M: Southern Midlands } \\
\text { N: South }\end{array}$ & $\begin{array}{l}1994 \text { : no information with record } \\
\text { (not vouchered) } \\
2017 \text { : could not be re-located despite } \\
\text { extensive search along ca. } 200 \text { m each } \\
\text { side of database record on both sides } \\
\text { of road }\end{array}$ & Presume grassy/weedy road verge. \\
\hline $\begin{array}{l}\text { Tunnack Main Road, S of } \\
\text { Parattah }\end{array}$ & $\begin{array}{l}\text { T: State Growth } \\
\text { I: South East } \\
\text { M: Southern Midlands } \\
\text { N: South }\end{array}$ & $\begin{array}{l}\text { 1996: no information with record } \\
\text { (not vouchered) } \\
\text { 2017: could not be re-located despite } \\
\text { extensive search along ca. } 200 \text { m each } \\
\text { side of database record on both sides } \\
\text { of road }\end{array}$ & Presume grassy/weedy road verge. \\
\hline $\begin{array}{l}\text { [Tunnack Road, ca. } 100 \\
\text { m SE of Beards Road } \\
\text { junction] }\end{array}$ & $\begin{array}{l}\text { T: State Growth } \\
\text { I: South East } \\
\text { M: Southern Midlands } \\
\text { N: South }\end{array}$ & $\begin{array}{l}\text { 1994: no information with record } \\
\text { (not vouchered) } \\
\text { 2017: could not be re-located despite } \\
\text { extensive search along ca. } 200 \text { m each } \\
\text { side of database record on both sides } \\
\text { of road }\end{array}$ & Presume grassy/weedy road verge. \\
\hline
\end{tabular}


APPENDIX 1 - cont.

\begin{tabular}{|c|c|c|c|}
\hline Location & $\begin{array}{c}\text { (T)enure } \\
\text { (I)BRA } \\
\text { (M) unicipality } \\
\text { (N)RM }\end{array}$ & Comments & Habitat \\
\hline $\begin{array}{l}\text { [junction Tunnack and } \\
\text { Inglewood roads] }\end{array}$ & $\begin{array}{l}\text { T: State Growth } \\
\text { I: South East } \\
\text { M: Southern Midlands } \\
\text { N: South }\end{array}$ & $\begin{array}{l}1994 \text { \& 2002: no information with } \\
\text { records (not vouchered) } \\
\text { 2017: could not be re-located despite } \\
\text { extensive search along ca. } 200 \text { m each } \\
\text { side of database records on both sides } \\
\text { of road }\end{array}$ & Presume grassy/weedy road verge. \\
\hline [Parattah railway line] & $\begin{array}{l}\text { T: TasRail } \\
\text { I: South East } \\
\text { M: Southern Midlands } \\
\text { N: South }\end{array}$ & $\begin{array}{l}\text { 2002: no information with record } \\
\text { (not vouchered) } \\
\text { 2017: could not be re-located despite } \\
\text { extensive search along ca. } 200 \text { m each } \\
\text { side of database record on both sides } \\
\text { of railway line }\end{array}$ & $\begin{array}{l}\text { Presume grassy/weedy verge of } \\
\text { railway line. }\end{array}$ \\
\hline $\begin{array}{l}\text { Township Lagoon Nature } \\
\text { Reserve [Tunbridge] }\end{array}$ & $\begin{array}{l}\text { T: Township Lagoon } \\
\text { Nature Reserve (PWS) } \\
\text { I: Northern Midlands } \\
\text { M: Northern Midlands } \\
\text { N: North }\end{array}$ & $\begin{array}{l}\text { 1991, 1992, 1993: } 4 \text { in unspecified } \\
\text { area for } 1991 \text { record (1992 vouchered } \\
\text { at HO) } \\
\text { 2014-2017: several searches by the } \\
\text { author and colleagues in the Township } \\
\text { Lagoon Nature Reserve havefaield to } \\
\text { re-detect the species }\end{array}$ & $\begin{array}{l}\text { "Themeda triandra grassland in } \\
\text { disturbed ground near tip". }\end{array}$ \\
\hline Lake River Church & $\begin{array}{l}\text { T: private } \\
\text { I: Northern Midlands } \\
\text { M: Northern Midlands } \\
\text { N: North }\end{array}$ & $\begin{array}{l}\text { 1991: “common" (vouchered at HO) } \\
\text { 2017: extensive search of cemetery } \\
\text { revealed no individuals }\end{array}$ & $\begin{array}{l}\text { "Under a large pine tree, well } \\
\text { mulched ground". Supporting } \\
\text { pine tree now removed. }\end{array}$ \\
\hline $\begin{array}{l}\text { Fingal, South Esk Highway, } \\
\text { north roadside }\end{array}$ & $\begin{array}{l}\text { T: uncertain } \\
\text { I: Ben Lomond } \\
\text { M: Break O’Day } \\
\text { N: North }\end{array}$ & $\begin{array}{l}\text { 1991: no information with records } \\
\text { (vouchered at HO) } \\
\text { 2017: extensive search of road verge } \\
\text { and in grassy cemetery yard nearly } \\
\text { opposite this site only resulted in } \\
\text { Lepidium pseudotasmanicum being } \\
\text { found. }\end{array}$ & $\begin{array}{l}\text { "Roadside under } P \text {. radiata with } \\
\text { Einadia nutans and Danthonia } \\
\text { racemosa". Trees have been } \\
\text { removed and species lost (A. } \\
\text { North pers. comm.), which was } \\
\text { confirmed. }\end{array}$ \\
\hline South Esk Highway, Fingal & $\begin{array}{l}\text { T: uncertain } \\
\text { I: Ben Lomond } \\
\text { M: Break O'Day } \\
\text { N: North }\end{array}$ & $\begin{array}{l}\text { 1991: no information with records } \\
\text { (vouchered at HO) } \\
\text { 2017: verges of main road through } \\
\text { Fingal surveyed with no evidence of } \\
\text { Lepidium hyssopifolium }\end{array}$ & $\begin{array}{l}\text { "Under } A \text {. dealbata in weed } \\
\text { infested site with } P \text {. lanceolata, } H \text {. } \\
\text { radicata". }\end{array}$ \\
\hline Fingal & $\begin{array}{l}\text { T: uncertain } \\
\text { I: Ben Lomond } \\
\text { M: Break O’Day } \\
\text { N: North }\end{array}$ & $\begin{array}{l}1984 \text { \& 1990: no information with } \\
\text { records (not vouchered) } \\
\text { 2017: see other Fingal records }\end{array}$ & No information available. \\
\hline Falmouth & $\begin{array}{l}\text { T: State Growth } \\
\text { I: Flinders } \\
\text { M: Break O'Day } \\
\text { N: North }\end{array}$ & $\begin{array}{l}1992 \text { \& } 1993 \text { \& 2002: no } \\
\text { information with records (not } \\
\text { vouchered) } \\
\text { 1995: no information with record } \\
\text { (vouchered at HO) } \\
\text { 2002: } 6 \text { in } 5 \mathrm{~m} 2 \\
\text { 2017: could not be re-located and it } \\
\text { seems that the species has been absent } \\
\text { since } 2006 \text { (A. North pers. comm.) }\end{array}$ & $\begin{array}{l}\text { Grassy Eucalyptus globulus forest } \\
\text { between road and paddock/ } \\
\text { plantation. }\end{array}$ \\
\hline
\end{tabular}

